\title{
ILLUSTRATIONS AND STUDIES IN NEOTROPICAL ORCHIDACEAE. THE SPECKLINIA CONDYLATA GROUP (PLEUROTHALLIDINAE) IN COSTA RICA AND PANAMA
}

\author{
Diego Bogarín ${ }^{1,2,3}, Z_{\text {Uleika Serracín }}^{2} \&$ Zabdy Samudio ${ }^{2}$ \\ ${ }^{1}$ Jardín Botánico Lankester, Universidad de Costa Rica. P.O. Box 302-7050 Cartago, Costa Rica, A.C. \\ ${ }^{2}$ Herbario UCH, Universidad Autónoma de Chiriquí, 0427, David, Chiriquí, Panama \\ ${ }^{3}$ Author for correspondence: diego.bogarin@ucr.ac.cr
}

\begin{abstract}
Taxonomy of discrete groups of taxa within Pleurothallidinae is critical for a better understanding of species diversity, evolution and phylogenetics. This paper focuses on the taxonomy and systematics of the species related to Specklinia condylata in Costa Rica and Panama. The taxonomic history and its phylogenetic position are discussed. The group is treated as comprising five species, three of them proposed as new to science. Each taxon is described on the basis of living material and illustrated in a composite plate. Overall distribution, maps, derivation of name, notes on species ecology, natural variation and diagnostic features are presented for each taxon. A key to the species and a comparative table is given to aid species identification.
\end{abstract}

ReSUMEN: La taxonomía de grupos discretos de taxones dentro Pleurothallidinae es fundamental para una mejor comprensión de la diversidad de especies, evolución y filogenética. Este documento se centra en la taxonomía y sistemática de las especies relacionadas a Specklinia condylata en Costa Rica y Panamá. Se discute su historia taxonómica y posición filogenética. El grupo comprende cinco especies, tres de ellas se proponen como nuevas para la ciencia. Cada taxón se describe con base en material vivo y se ilustra en una lámina compuesta. Para cada taxón se presenta la distribución general, mapas, derivación del nombre, notas sobre ecología, variación natural y características diagnósticas. Se proporciona una clave para las especies y un cuadro comparativo para ayudar a la identificación de especies.

Key words / Palabras clave: new species, Platystele, Sarcinula, Scaphosepalum, taxonomy

Lindley (1830) established Specklinia Lindl. to include five species close to Pleurothallis R. Br. Lindley did not choose a type for the genus. In Folia Orchidacea, Lindley (1859) himself decided to merge the poorly defined group of about a dozen species contained in Specklinia into a broad concept of Pleurothallis. More than a century later, Garay \& Sweet (1972) designated the orange-flowered $S$. lanceola (Sw.) Lindl. (=Epidendrum lanceola Sw.) as the lectotype of Specklinia. Then, Garay (1974) determined to treat Specklinia under Pleurothallis s.l. and proposed to classify the group under Pleurothallis subgenus Specklinia (Lindl.) Garay.
Luer (1986) followed Garay in considering those species under a broad concept of Pleurothallis and created in addition two new subgenera: Empusella Luer and Pseudoctomeria Kraenzl. (Luer) and sections Muscariae Luer and Tribuloides Luer.

Species of Specklinia remained in Pleurothallis until Pridgeon \& Chase (2001) assessed the monophyly of Pleurothallidinae. In one of the most parsimonious trees of the complete ITS nrDNA matrix, they found that $S$. lanceola belongs to a clade (treated as Scaphosepalum clade or Clade F) encompassing the species of subgenera Specklinia (sect. Hymenodanthe Barb.Rodr., Muscariae and

* This contribution was prepared as part of the special edition of LANKESTERIANA aimed to celebrate Lankester Botanical Garden's (JBL) 40th anniversary. 
Tribuloides), Empusella and Pseudoctomeria, together with the traditionally accepted genera Acostaea Schltr., Dryadella Luer, Platystele Schltr. and Scaphosepalum Pfitzer. Pridgeon \& Chase (2001) and Luer (2006) published numerous transfers to Specklinia, making the genus large and difficult to define morphologically. Luer (2006) regarded the new circumscription of Pridgeon \& Chase (2001) as a polyphyletic aggregation of many taxa. Instead, he proposed to split Specklinia into 13 genera: the five major groups of Muscarella Luer, Pabstiella Brieger \& Senghas, Panmorphia Luer, Sarcinula Luer and Specklinia; the smaller groups of Phloeophila Hoehne \& Schltr., Ronaldella Luer, Sylphia Luer and Tribulago Luer; and four other monospecific genera created for the rest of the morphologically "aberrant" species Luer (2006).

Different interpretations of the morphologic and phylogenetic evidence make Specklinia difficult to define. Almost 500 binomials attributed to the genus have been published but the exact number of species is still hard to calculate and it depends on the acceptance and definition of the groups within the clades (Pupulin et al. 2012). When Pridgeon \& Chase (2001) redefined the genus, they recognized 86 species. In Pridgeon (2005), Specklinia was treated as comprising some 200 species, ranging from Mexico and the West Indies to Brazil and Bolivia.

Specklinia is still variable in terms of vegetative and floral morphology, however the genus can be recognized by the caespitose small plants with ramicauls shorter than the leaves, an abbreviated stem with an annulus, the leaves erect, elliptic, obovate or orbicular, coriaceous, the sepals and petals mostly acute or obtuse, membranous, the lateral sepals variously connate, the petals oblong-spatulate, acute or obtuse and the lip is hinged to the column foot. The column is winged, terete or clavate, with an erose or toothed clinandrium. The anther and stigma are ventral. The pollinarium is made up by two pollinia, free or lightly adherent to minute viscidia (Bogarín et al. 2013, Luer 2006, Pupulin et al. 2012, Pridgeon et al. 2005).

This paper is focused on a group of Specklinia that comprises the species close to $S$. condylata (Luer) Pridgeon \& M.W.Chase. Here, it is informally treated as $S$. condylata group.
The Specklinia condylata Group. The first plant to be known of this group was collected by Augustus R. Endrés in the Pacific watershed of Cordillera de Talamanca in the locality of "Boca de Dota, towards Cerro Pito" in Costa Rica. He depicted the plant in a fine drawing accompanied with a detailed description, however the species was never published (W0020241). Luer (1976) described the same species as Pleurothallis condylata based on a plant collected in western Panama around San Vicente de La Concepción, Chiriquí at $500 \mathrm{~m}$ of elevation. Luer (1976) compared the plant with P. brighamii S. Watson and its allies however the flower was described as comparatively larger, with yellow sepals and petals and dispersed purple-red dots or speckles. The purple, cuneate lip had the apex folded or decurved, appearing truncate. Luer (2006) also suggested a close relationship with $S$. areldii (Luer) Pridgeon \& M.W.Chase from western Panama, a species with obovate, wider leaves, which we exclude from the $S$. condylata group because the acuminate sepals and the oblong lip, features that resemble more the flowers of S. acrisepala (Ames \& C. Schweinf.) Pridgeon \& M.W. Chase.

In general, plant morphology is fairly uniform and it is almost imposible to identify a specimen without flowers [even other closely allied species are quite similar when they are not in bloom i.e: $S$. acrisepala and S. brighamii (S.Watson) Pridgeon \& M.W.Chase]. The separation among species is largely based on floral characters and/or the sum of a set of differences. Although, the group can be characterized mainly by the caespitose plants to $5.0-8.5 \mathrm{~cm}$ tall, with ramicauls enclosed by two tubular sheaths at base, the elliptic, oblong or obovate, coriaceous, conduplicate leaves, narrowing into a short petiole, the racemose inflorescences developed into a filiform peduncle with the rachis congested appearing fasciculate and the imbricate floral bracts covering the persistent pedicels forming like a mass of old bracts and pedicels. The flowers are produced successively and singly; the sepals and petals are entire, smooth, acute or obtuse, tailless, frequently speckled, maculate or stained; the lateral sepals are connate at the base, sometimes shallowly so, often forming a synsepal; and the petals widen towards the middle. The lip is oblong, spatulate or pandurate, always mostly purple, arcuate, entire, denticulate or erose, sulcate with a pair of longitudinal, 
parallel, apically convergent keels running up to the apex, basally glandular-trichomate, glutinose from the base towards the apex and between the calli on the median groove, hinged to the column foot. The apex is acute or obtuse but can be often curved downward so appearing retuse or emarginate. The column is arcuate, toothed and erose at apex. The anther and stigma are ventral and the pollinarium is made up by a pair of free, ovoid pollinia ending in a small hook at the base. The plants treated in this study are restricted to the tropical moist and wet forest from the central Pacific in Costa Rica towards western Panama at elevations between 300-1640 m (mostly between 300-600 m). They are somewhat common and can be found along streams and rivers in warm, humid areas in gallery forest, edges of primary forest or disturbed vegetation (Luer 2003). They mostly flower through the year. Potential pollinators have not been observed. The flowers produce a foetid, carrion-like smell in $S$. berolinensis, perhaps attracting flies.

Pridgeon et al. (2001) evaluated the phylogenetic position of $S$. brighamii and $S$. condylata. In one of the most parsimonious trees of the ITS nrDNA, both species were grouped into a subclade sister to Platystele and Scaphosepalum. The previous subclade is sister to another subclade comprising the species allied to S. lanceola, the type of Specklinia. However, the position of $S$. brighamii-condylata as sister to Platystele and Scaphosepalum is weakly supported (equally weighted bootstrap percentages $<\% 50$ ) in the ITS nrDNA analysis. Thus, the subclade $S$. brighamiicondylata is absent in the strict consensus tree from the combined matK/trnL-F/ITS nrDNA data set. In that combined analysis, the type clade of Specklinia is sister to the Scaphosepalum-Platystele clade with 95\% support. Although the position of S. brighamiicondylata is not clear in Pridgeon \& Chase (2001), they decided to transfer both species and their allies into Specklinia.

Luer (2002) considered that Specklinia as proposed by Pridgeon \& Chase (2001) is still polyphyletic and suggested retaining the species in Pleurothallis. Later, Luer (2006) proposed to classify $S$. condylata, along with 24 other species, in Sarcinula, a genus characterized by the caespitose plants (similar to many others), elongated peduncles with a succession of overlapping floral bracts and a "fascicle" of pedicels forming a extremely congested raceme. The sepals are tailless and variously connate and the petals are acute or obtuse, widened towards the middle and always entire. Some species of Muscarella and Panmorphia also share the "fasciculate" congested raceme however the acuminate or tailed, fringed, denticulate or fimbriate sepals and shape of the lip distinguish them from Sarcinula (Luer 2006). Nevertheless, as proposed by Luer (2006), Sarcinula is polyphyletic and certainly includes several species embedded within the type clade of Specklinia, as found by Pupulin et al. (2012). Among them are the "orange-flowered" Specklinia barbae (Schltr.) Luer, S. chontalensis (A.H.Heller \& A.D.Hawkes) Luer, S. corniculata (Sw.) Steud., S. fulgens (Rchb.f.) Pridgeon \& M.W.Chase, $S$. guanacastensis (Ames \& C.Schweinf.) Pridgeon \& M.W.Chase and S. psichion (Luer) Luer. The type clade also encompasses: S. lentiginosa (F. Lehm. \& Kraenzl.) Pridgeon \& M.W. Chase, S. tribuloides (Sw.) Pridgeon \& M.W.Chase and S. endotrachys (Rchb.f.) Pridgeon \& M.W.Chase and its allies (Pupulin et al. 2012). The type of Sarcinula, Specklinia acicularis (Ames \& C. Schweinf.) Pridgeon \& M.W. Chase, has not been yet evaluated phylogenetically, however it is morphologically different from the species allied to S. brighamii-condylata as it has thick, acicular leaves (vs. oblong-elliptic, conduplicate) and the sepals are cellular-glandular, spiculate within (vs. glabrous).

The phylogenetic position of $S$. brighamiicondylata group is still subject of evaluation. Preliminary evidence presented in Bogarín et al. (2013) showed both species in a subclade basal to Specklinia s.s. The Specklinia clade which includes $S$. lanceola and its allies, S. absurda Bogarín, Karremans \& R.Rincón, S. fuegii (Rchb.f.) Solano \& Soto Arenas, [=Sylphia fuegii (Rchb.f.) Luer], S. grobyi (Bateman ex Lindl.) F. Barros, S. picta (Lindl.) Pridgeon \& M.W. Chase and S. costaricensis (Rolfe) Pridgeon \& M.W. Chase is again sister to the ScaphosepalumPlatystele clade (Bogarín et al. 2013, Pupulin et al. 2012, Pridgeon et al. 2001). Species closely allied to the $S$. condylata group include at least: Specklinia acrisepala, S. alexii (A.H. Heller) Pridgeon \& M.W. Chase, S. areldii, S. brighamii, S. calderae (Luer) Luer, S. scolopax (Luer \& R. Escobar) Pridgeon \& M.W. Chase and S. simmleriana (Rendle) Luer. 
A solid taxonomic basis is critical for phylogenetic evaluations. This paper is part of a series of contributions on the taxonomy of discrete groups of taxa within Specklinia s.l., and other allied genera, intended for a better understanding of species diversity within clades and future phylogenetic evaluations. Here, we clarify the taxonomy of the $S$. condylata group. Fieldwork activities in Costa Rica and Panama led to the discovery of three new species allied to $S$. condylata that are here described and illustrated. Additional data related to $S$. vierlingii Baumbach are provided and discussed. Data on distribution, habitat and ecology, etymology, phenology and variation among populations are given for each species. A key to the species and a comparative table is given to aid species identification.

Materials and Methods. This study was performed at Jardín Botánico Lankester (JBL) and the Herbario UCH of the Universidad Autónoma de Chiriquí, Panamá. Sketches and images were prepared from living specimens with a Leica ${ }^{\circledR}$ MZ 9.5 stereomicroscope with drawing tube, Nikon ${ }^{\circledR}$ D5100 digital camera with a AF-S VR Micro-NIKKOR $105 \mathrm{~mm}$ f/2.8G IFED lens and Epson Perfection Photo Scanner V600. Composite plates were diagrammed as consistently as possible to facilitate species comparison by using Adobe Photoshop ${ }^{\circledR}$. Ink drawings were prepared in smooth Fabriano ${ }^{\circledR}$ paper of $240 \mathrm{~g} / \mathrm{m} 2$ with a Rotring ${ }^{\circledR}$ Rapidograph $0.1 \mathrm{~mm}$ using black capillary cartridges and traced in Artograph LightPad ${ }^{\circledR}$ A920. Specimens at JBL (from living and spirit collections), and dried and spirit material available at $\mathrm{CR}, \mathrm{INB}, \mathrm{JBL}, \mathrm{L}, \mathrm{UCH}$ and USJ were reviewed. The new species were illustrated from living specimens. Phenological data were recorded in the field, herbarium labels and from cultivated specimens. Ecological zones were estimated by using the Holdridge Life Zone System (Holdridge 1987) and the Mapa Ecológico de Costa Rica by Bolaños et al. (2005). The map and georeferences for specimens were obtained by using a Garmin eTrex Vista GPS, Google Earth 6.1.0 $@$ and the EPIDENDRA (www.epidendra.org) database. The identity of $S$. condylata was studied by interpreting electronic images of the holotype of $S$. condylata available at SEL and EPIDENDRA together with the protologue (Luer 1976). A visit to the type locality was organized in order to complement the interpretation of the type specimen with living material and to assess its natural variation. The plants gathered were documented by pictures and ink drawings following the procedures already described and deposited at $\mathrm{UCH}$.

\section{Taxonomic treatment}

\section{Specklinia acoana Bogarín, sp. nov.}

TYPE: Costa Rica. San José: Pérez Zeledón, Platanares, near Villa Argentina, ca. $9^{\circ} 10^{\prime} 47^{\prime \prime} \mathrm{N} 83^{\circ} 38^{\prime} 57^{\prime \prime} \mathrm{W}$, $950 \mathrm{~m}$, recolectada por Jeremy Quesada, floreció en cultivo en el vivero de orquídeas de Gerson Villalobos en San Miguel de Santo Domino de Heredia, 27 octubre 2011, D. Bogarín 9352 (holotype, JBL). Figs. 1, 2A, 2B, 3, 4A.

The combination of whitish flowers with dispersed stains and blotches on the sepals and petals; the spatulate, minutely denticulate lip, less than $5 \mathrm{~mm}$ long; and the connate sepals to $5 \mathrm{~mm}$ forming a concave synsepal to $12.0 \times 7.0 \mathrm{~mm}$ distinguish $S$. acoana from its close allies.

Epiphytic, caespitose herb, up to $8.5 \mathrm{~cm}$ tall. Roots slender, flexuous, to $0.5 \mathrm{~mm}$ in diameter. Ramicauls slender, erect, 5-6 mm long, enclosed by 2 tubular sheaths up to $1 \mathrm{~cm}$ long. Leaves narrowly elliptic to obovate thick, coriaceous, acute, conduplicate, emarginate, with a short apiculus, $2.7-7.5 \times 0.8-1.2 \mathrm{~cm}$, cuneate, the base narrowing into an indistinct petiole less than $1 \mathrm{~cm}$ long. Inflorescence racemose, distichous, glabrous, patent, erect or suberect, successively singleflowered, born by a slender filiform peduncle, the rachis congested, appearing fasciculate, shorter than the leaves, up to $3.7 \mathrm{~cm}$ long, peduncle up to $3.3 \mathrm{~cm}$ long, rachis up to $0.4 \mathrm{~cm}$ long. Floral bracts ovate, acute, conduplicate, membranaceous, tubular, imbricating, up to $3 \mathrm{~mm}$ long. Pedicel $5 \mathrm{~mm}$ long, persistent. Ovary to $2 \mathrm{~mm}$ long, glabrous, green. Flowers the sepals and petals whitish-yellowish with purple-red stains, the lip purple, the column greenish with purple stains, anther cap reddish. Dorsal sepal ovate-elliptic, acute, entire, concave, 3-veined, dorsally keeled, connate to the lateral sepals for about $2 \mathrm{~mm}, 11 \times 5 \mathrm{~mm}$. Lateral sepals oblong, acute, connate for $5 \mathrm{~mm}$, forming a mentum at base, 3-veined, dorsally keeled, $12 \times 7 \mathrm{~mm}$. Petals oblique, ovate-lanceolate, cuneate, acute, 3 -veined, 4.1 $\times 2.6 \mathrm{~mm}$. Lip spatulate, obovate, basally unguiculate, 

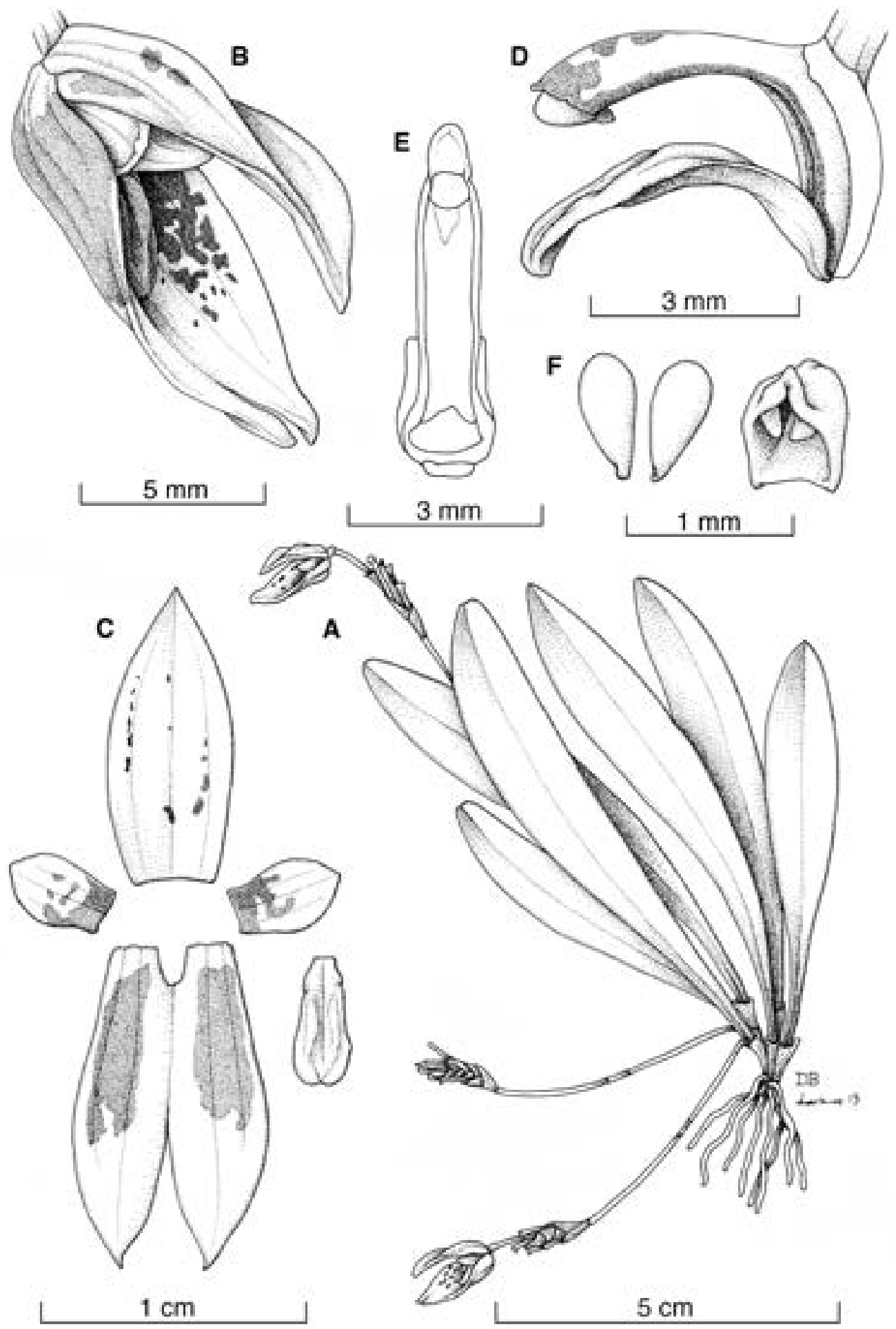

Figure 1. Specklinia acoana Bogarín. A - Habit. B - Flower. C - Perianth, flattened. D - Column and lip, side view. E - Column. F - Pollinarium and anther cap. Drawn from the holotype by D. Bogarín and D. Solano. 

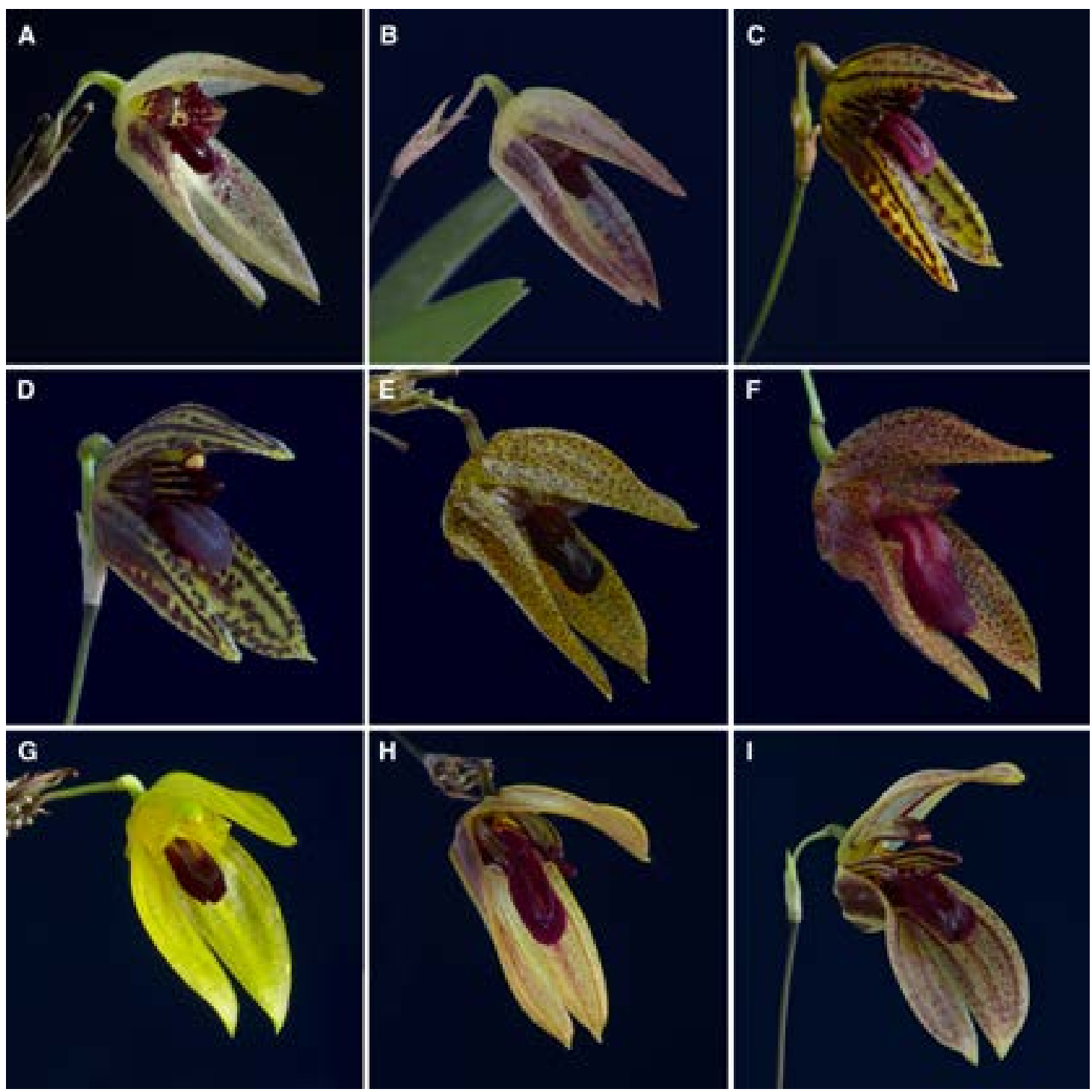

FIGURE 2. Flower morphology of: A. Specklinia acoana (D. Bogarín 9352). B. Specklinia acoana (JBL-11957). C. Specklinia berolinensis (F. Pupulin 2325). D. Specklinia berolinensis (A. Karremans 5807). E. Specklinia condylata (D. Bogarín 10364). F. Specklinia condylata (D. Bogarín 7855). G. Specklinia icterina (D. Bogarín 8767). H. Specklinia vierlingii (F. Pupulin 2894). I. Specklinia vierlingii (D. Bogarín 7350).

with a pair of small lobules at the middle, adnate to the column foot, slightly erose, arcuate, obtuse, with two longitudinal, parallel, apically convergent keels running up to the apex, sulcate, basally glutinose from the base towards the apex between the calli, $5.0 \times 2.2$ $\mathrm{mm}$, the apex obtuse but often curved downward so appearing retuse. Column cylindric, footed, to $5.2 \mathrm{~mm}$ long, erose, the anther and stigma ventral, greenish stained with purple. Pollinia two, ovoid, without viscidium, ending in a hook. Anther cap cucullate, white, stained with purple.

Distribution: endemic to the southern Pacific of Costa Rica (Fig. 3).

Habitat AND ECOLOGY: epiphytic in tropical moist forest, tropical moist forest premontane belt transition in secondary and primary vegetation at around 500$800 \mathrm{~m}$ of elevation. 
ETymology: named after Asociación Costarricense de Orquideología (A.C.O) founded in 1970 by a group of orchid enthusiasts led by Miguel Angel Ramírez, Dorothy Lankester, Rafael Lucas Rodríguez Caballero, Roy Lent and Margarita de Lent among others with the support of the Latin-American Committee of Orchidology and Helena Baraya de Ospina, former President of the Sociedad Colombiana de Orquideología. A.C.O's efforts through Rafael Lucas Rodríguez were crucial to save the orchid garden of Charles H. Lankester at "El Silvestre" that was later transferred to the University of Costa Rica on March $2,1973$.

Phenology: plants flower through the year but mostly from October to November.

The combination of whitish flowers with dispersed stains and blotches on the sepals and petals; the spatulate, minutely denticulate lip, $5 \mathrm{~mm}$ long; and the sepals connate to $5 \mathrm{~mm}$ forming a concave synsepal to $12.0 \times 7.0 \mathrm{~mm}$ distinguish $S$. acoana from other members of the group. It is most similar to $S$. condylata, however the latter has yellowish flowers with dispersed speckles on the sepals and petals (vs. whitish with blotches and stains) and the lip is longer, $>7.5 \mathrm{~mm}$ long and wider $>3.0 \mathrm{~mm}$ (vs. $\sim 5.0 \mathrm{~mm}$ long, $<2.2 \mathrm{~mm}$ wide), pandurate (vs. spatulate to oblong) and the callus is made up by two prominent whitishyellowish cushions at the middle (vs. two purple low keels) (Fig. 4A). For a detailed comparison among its allies see Table 1 .

Additional material examined: Costa Rica. San José: Pérez Zeledón, Rivas, brought to Jardín Botánico Lankester by D. Jiménez s.n., June 26, 2012 (JBLspirit). Without locality data, flowered in cultivation at Jardín Botánico Lankester, Universidad de Costa Rica, October 31, 2009, JBL-11957 (JBL-spirit) (Fig. 2B).

Specklinia berolinensis Bogarín, sp. nov.

TYPE: Costa Rica. San José: Pérez Zeledón, San Ramón Norte, trail to the summit of Cerro Pelón, 1420-1640 m, secondary mature and primary lower montane moist forest, 3 May 2000, F. Pupulin 2325,

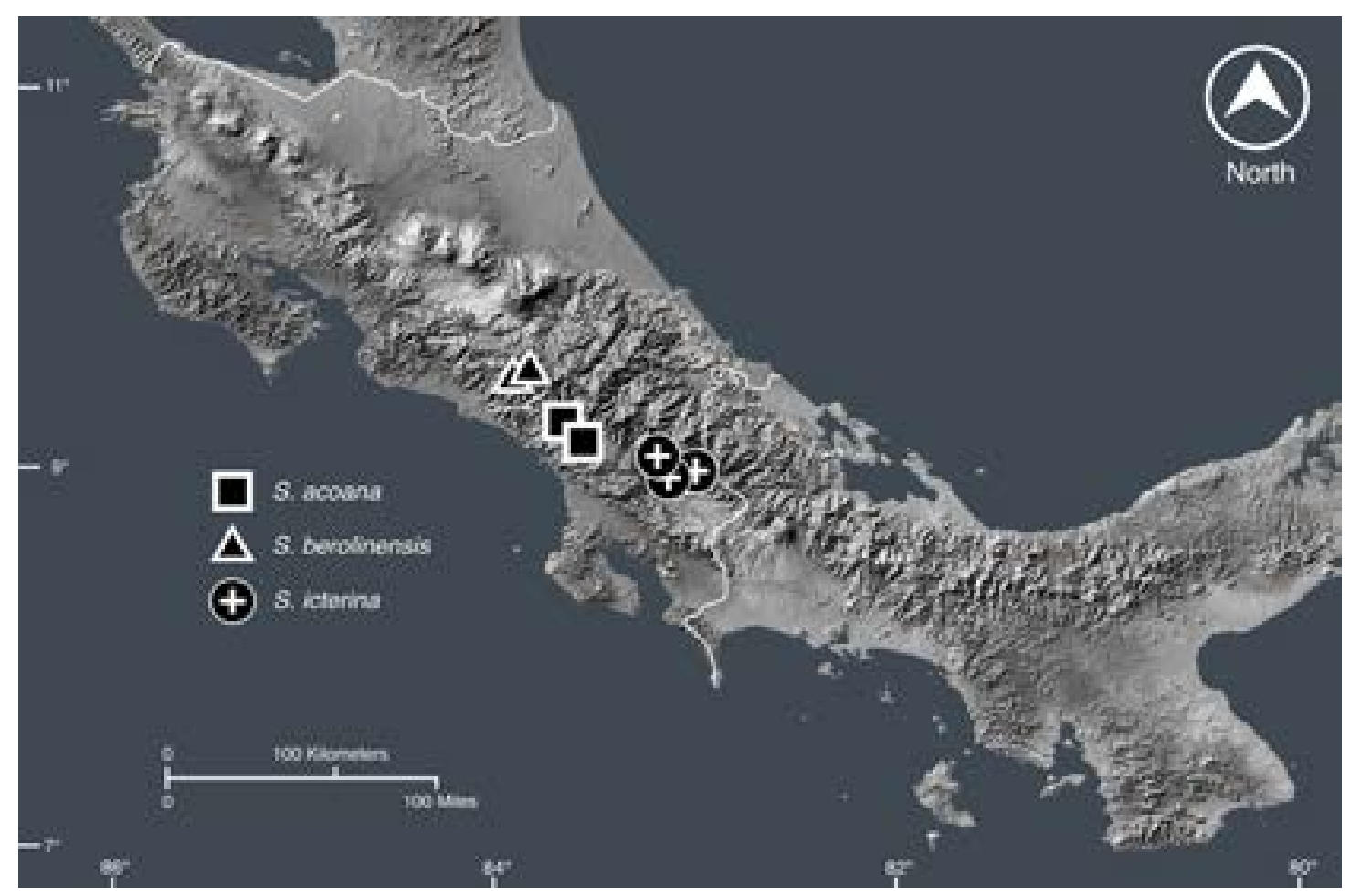

FIGURE 3. Geographic distribution of Specklinia acoana, Specklinia berolinensis and Specklinia icterina. 


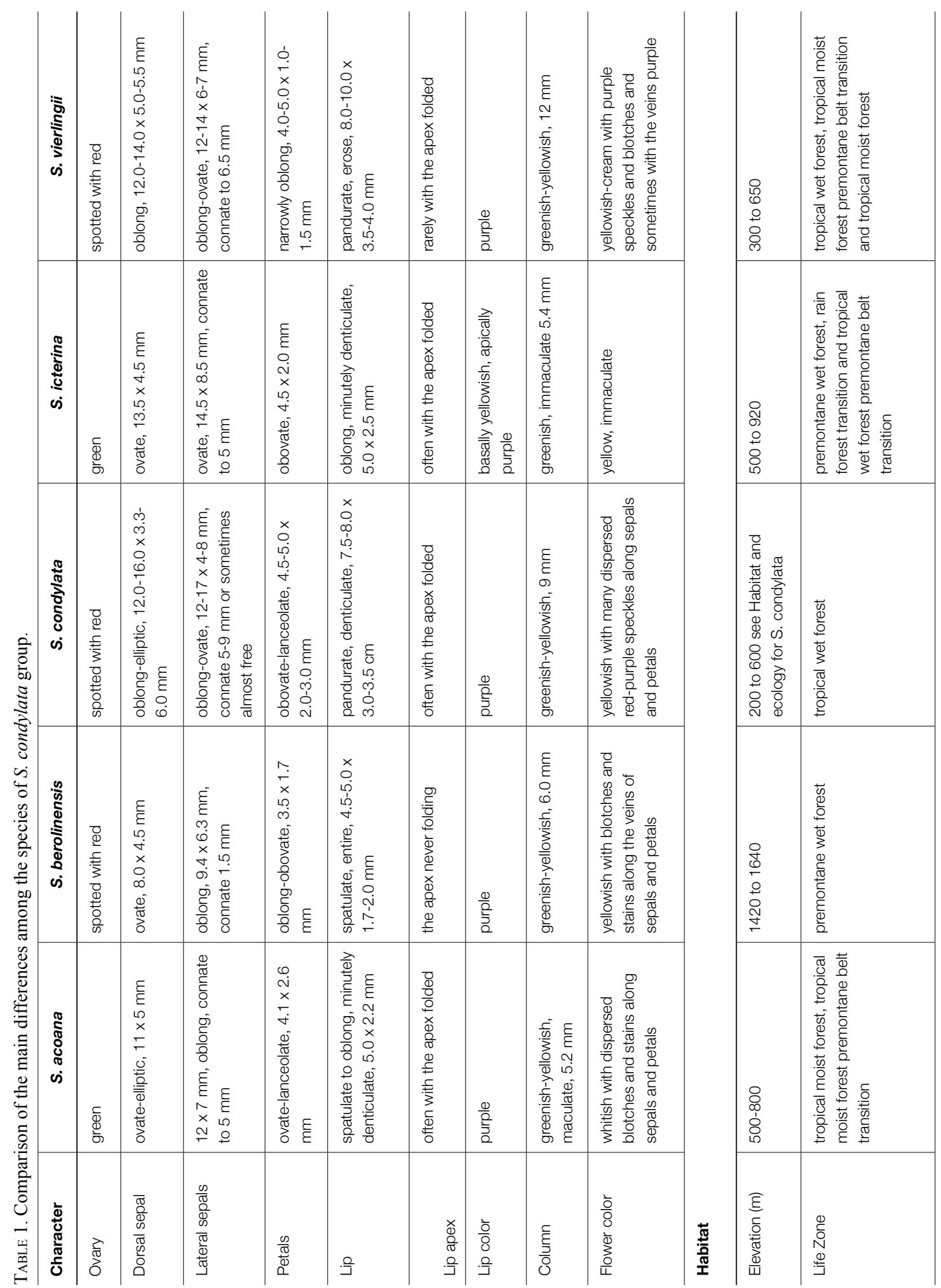




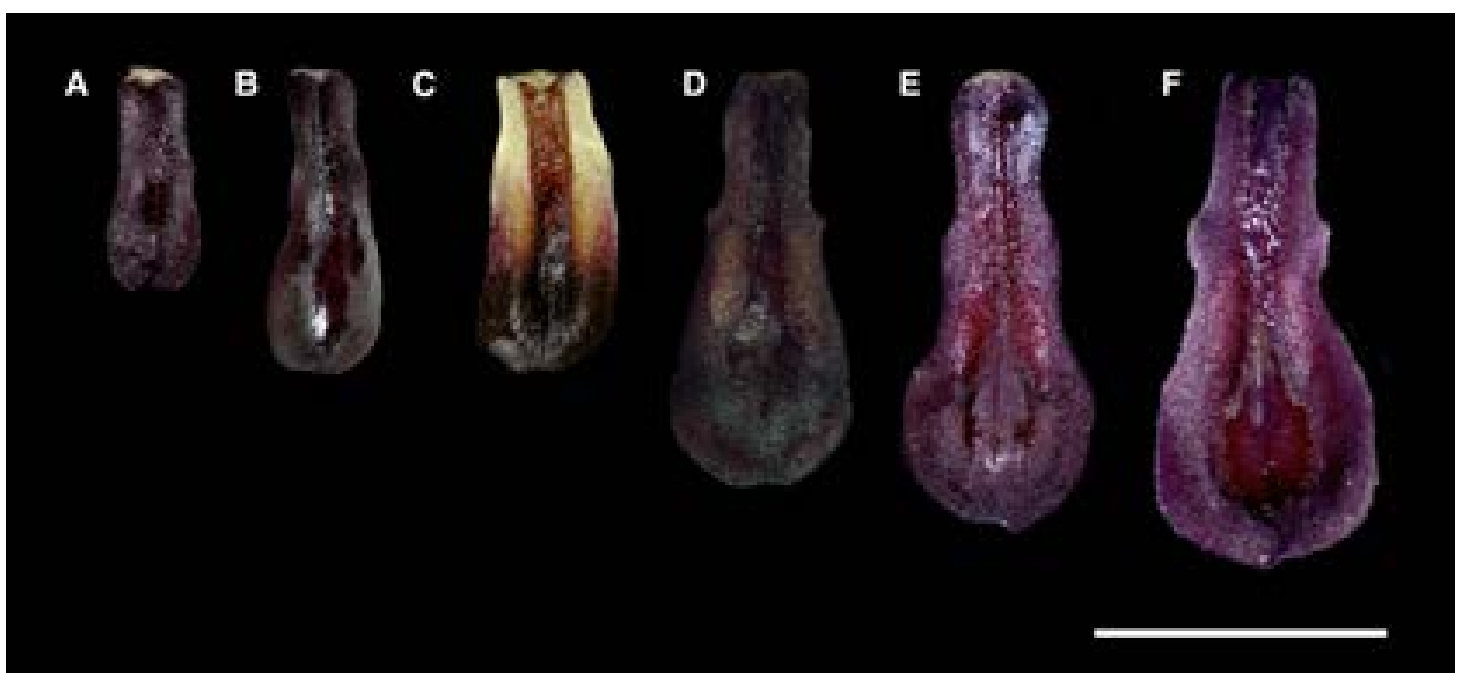

Figure 4. Comparison of lips (front view): A. Specklinia acoana (D. Bogarín 9352). B. Specklinia berolinensis (F. Pupulin 2325). C. Specklinia icterina (D. Bogarín 8767). D. Specklinia condylata (D. Bogarín 10364). E. Specklinia condylata (D. Bogarín 7855). F. Specklinia vierlingii (F. Pupulin 2894). Scale bar $=5 \mathrm{~mm}$.

L. Spadari, J. Cambronero, V. Juárez-Pérez \& K. Granado (holotype, JBL). Figs. 2C, 2D, 3, 4B, 5.

Specklinia berolinensis is distinguished by the yellowish flowers with purple blotches, stains and stripes along the veins of the sepals and petals, the smaller sepals $<3.5 \mathrm{~mm}$ long, the dorsal sepal $<8$ mm long and lateral sepals $<9.5 \mathrm{~mm}$ long, the lateral sepals almost free and not developing an evident synsepal and the entire lip with rounded apex, never folding or curved down apically.

Epiphytic, caespitose, pendent or suberect herb, up to $8 \mathrm{~cm}$ tall. Roots slender, flexuous, to $0.5 \mathrm{~mm}$ in diameter. Ramicauls slender, erect, terete, to $7 \mathrm{~mm}$ long, enclosed by 2 tubular sheaths up to $1 \mathrm{~cm}$ long. Leaves narrowly obovate thick, coriaceous, acute, conduplicate, emarginate, with a short apiculus, 3.5$8.0 \times 0.6-0.9 \mathrm{~cm}$, cuneate, the base narrowing into a indistinct petiole less than $4 \mathrm{~mm}$ long. Inflorescence racemose, distichous, glabrous, patent or creeping down, successively single-flowered, producing one flower at once, born by a slender filiform peduncle; peduncle bracts tubular to $3 \mathrm{~mm}$ long, the rachis congested appearing fasciculate, up to $6.5 \mathrm{~cm}$ long, peduncle $3-4 \mathrm{~cm}$ long, rachis up to $1.5 \mathrm{~cm}$ long. Floral bracts tubular, apiculate, conduplicate, membranaceous, imbricating, up to $4 \mathrm{~mm}$ long. Pedicel $5 \mathrm{~mm}$ long, persistent. Ovary to $2 \mathrm{~mm}$ long, glabrous, green spotted with red. Flowers hyaline, whitish or greenish, the sepals stained with purple red along the veins with few dispersed purple dots in between, the dorsal sepal adaxially striped with purple, the petals yellowish with purple stripes and purple apex, the lip purple, the column greenish-yellow with purple red stripes along the margin. Dorsal sepal ovate, acute, entire, reflexed, concave, 3-veined, dorsally keeled, connate to the lateral sepals for about $1.5 \mathrm{~mm}, 8.0 \times$ $4.5 \mathrm{~mm}$. Lateral sepals oblong, acute, connate for 1.5 $\mathrm{mm}$, forming a mentum at base, 3-veined, dorsally keeled, $9.4 \times 6.3 \mathrm{~mm}$. Petals oblique, oblong-obovate, cuneate, acute, 3 -veined, $3.5 \times 1.7 \mathrm{~mm}$. Lip spatulate, oblong-obovate, basally unguiculate, with a pair of small lobules at the middle, adnate to the column foot, entire, arcuate, rounded, with two longitudinal, parallel, apically convergent keels running up to the apex, sulcate, basally glutinose from the base towards the apex between the keels, 4.5-5.0 $\times 1.7-2.0 \mathrm{~mm}$. Column cylindrical, footed, to $6 \mathrm{~mm}$ long, with a pair of apical arms, erose, the anther and the stigma ventral, greenish stained with purple. Pollinia two, ovoid, without viscidium, ending in a hook. Anther cap cucullate, white, stained with purple.

Distribution: restricted to the type locality at Berlín de Páramo de Pérez Zeledón, San José in the neighbouring areas of Fila Temblor, Fila Zapotales, Cerro Pelón and 


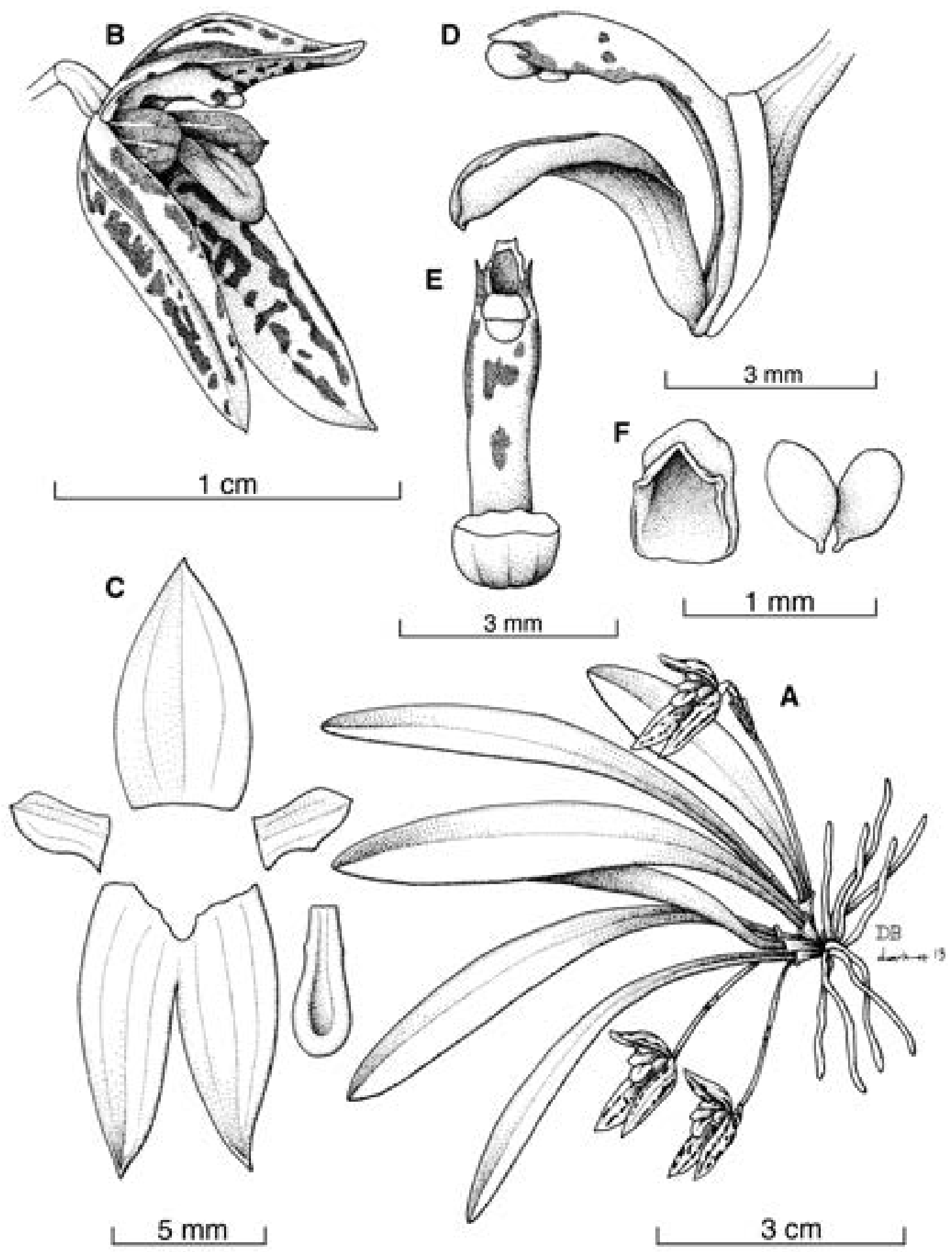

FiguRe 5. Specklinia berolinensis Bogarín. A - Habit. B - Flower. C - Perianth, flattened. D - Column and lip, side view. E - Column. F - Pollinarium and anther cap. Drawn from the holotype by D. Bogarín and D. Solano. 
the headwaters of río División in the Pacific watershed of Cordillera de Talamanca in Costa Rica. (Fig. 3).

HaBitat AND ECOLOgY: epiphytic in premontane wet forest along the edge of primary forest in trunks with mosses from 1420 to $1640 \mathrm{~m}$ of elevation.

Eтymology: named after the locality of Berlín de Pérez Zeledón, San José where this species is restricted.

Phenology: plants flower through the year but mostly from August to November.

Compared to its allies, $S$. berolinensis is distinguished by the yellowish flowers with purple blotches, stains and stripes along the veins of the sepals and petals (vs. dispersed speckles or blotches); the smaller sepals $<3.5 \mathrm{~mm}$ long (vs. $>4 \mathrm{~mm}$ ) (see Table 1); the dorsal sepal $<8 \mathrm{~mm}$ long (vs. $>11 \mathrm{~mm}$ ) and lateral sepals $<9.5 \mathrm{~mm}$ long (vs. $>12 \mathrm{~mm}$ ); the lateral sepals almost free (connate for about $1.5 \mathrm{~mm}$ ) and not developing an evident synsepal (vs. connate $>5 \mathrm{~mm}$, developing an evident synsepal) and the entire lip, with rounded apex, never folding or curved down apically (vs. denticulate or erose, acute or obtuse and folding apically) (Fig. 4B). The inflorescences are patent but sometimes they are creeping down, prostrate on the substrate, just curving up when the first bud is mature. Specklinia berolinensis is found at higher elevations (between 1420 to $1640 \mathrm{~m}$ ) in comparison to its allies that have been recorded from lower elevations $(<920$ $\mathrm{m}$, mainly between 300-600 m).

Specklinia berolinensis and $S$. condylata are quite different species separated mainly by the size and color of the flowers which are yellowish with blotches and stains along the veins of sepals and petals (vs. yellowish with many dispersed red-purple speckles along sepals and petals), the spatulate, entire, shorter lip to 4.5-5.0 $\times 1.7-2.0 \mathrm{~mm}$ (vs. pandurate, denticulate, larger to $7.5-8.0 \times 3.0-3.5 \mathrm{~cm}$ ) which never folds apically (vs. folding apically) and without two prominent cushions at the middle (vs. with prominent whitish-yellowish cushions at the middle). Flowers of $S$. berolinensis produce a strong carrion-like smell in the afternoon and evening similar to that of $S$. vierlingii but no smell has been perceived for $S$. condylata. Plants of both species are vegetatively similar but $S$. berolinensis has narrower leaves $<0.9 \mathrm{~cm}$ long whereas $S$. condylata has wider leaves $>0.9 \mathrm{~cm}$ long and up to $1.2 \mathrm{~cm}$. Here, we accept $S$. condylata as a species ranging from the central Pacific of Costa Rica towards western Panama. This species shows variation in size of the flowers, the lip apex and coloration (see Table 1 and discussion of S. condylata). However this variation does not overlap with the features observed in $S$. berolinensis. The color and size of the flowers of $S$. berolinensis are consistent among the populations studied. Those features were not observed in the variation range of any of the populations of $S$. condylata.

Additional material examined: Costa Rica. San José: Pérez Zeledón, San Ramón Norte, trail to the summit of Cerro Pelón, 1420-1640 m, secondary mature and primary lower montane moist forest, 3 May 2000, F. Pupulin 2326, L. Spadari, J. Cambronero, V. JuárezPérez \& K. Granado (JBL-spirit). San José: Pérez Zeledón, Berlín, A. Quesada-Chanto s.n. (JBLspirit). Pérez Zeledón, Páramo, Berlín, Purruja, Fila Temblor, ca. $2 \mathrm{~km}$ al noroeste de Berlín, 9॰26’ $13.22^{\prime \prime} \mathrm{N}$ $83^{\circ} 46^{\prime} 41.97$ 'W, $1429 \mathrm{~m}$, bosque pluvial premontano, en bosque secundario, 21 marzo 2013, A.Karremans $5807 \&$ D. Bogarin (JBL-spirit) (Fig. 2D).

Specklinia condylata (Luer) Pridgeon \& M.W. Chase, Lindleyana 16(4): 257. 2001. Pleurothallis condylata Luer, Selbyana 3(1-2): 80-81, f. 143. 1976. Sarcinula condylata (Luer) Luer, Monogr. Syst. Bot. Missouri Bot. Gard 105: 208. 2006.

TYPE: Panama. Chiriqui: epiphytic in trees along the stream near San Vicente, alt. 500 m., between Concepción and Volcán, 11 Sept 1976, C. Luer \& H. Butcher 1198 (holotype, SEL). Figs. 2E, 2F, 4D, 4E, 6, 7, 8, 9, 10.

Epiphytic, caespitose, pendent or suberect, herb, up to $8 \mathrm{~cm}$ tall. Roots slender, flexuous, to 0.5 $\mathrm{mm}$ in diameter. Ramicauls slender, erect, 5-8 mm long, enclosed by 2 tubular sheaths up to $1 \mathrm{~cm}$ long. Leaves narrowly obovate, thick, coriaceous, acute, conduplicate, emarginate, with a short apiculus, 3.5$8.0 \times 0.9-1.2 \mathrm{~cm}$, cuneate, the base narrowing into a indistinct petiole less than $4 \mathrm{~mm}$ long. Inflorescence racemose, distichous, glabrous, pendent or suberect, successively single-flowered, producing one flower at once, born by a slender filiform peduncle; peduncle bracts tubular to $3 \mathrm{~mm}$ long, the rachis congested, appearing fasciculate, $3.5-6.0 \mathrm{~cm}$ long, peduncle 3.5 - 


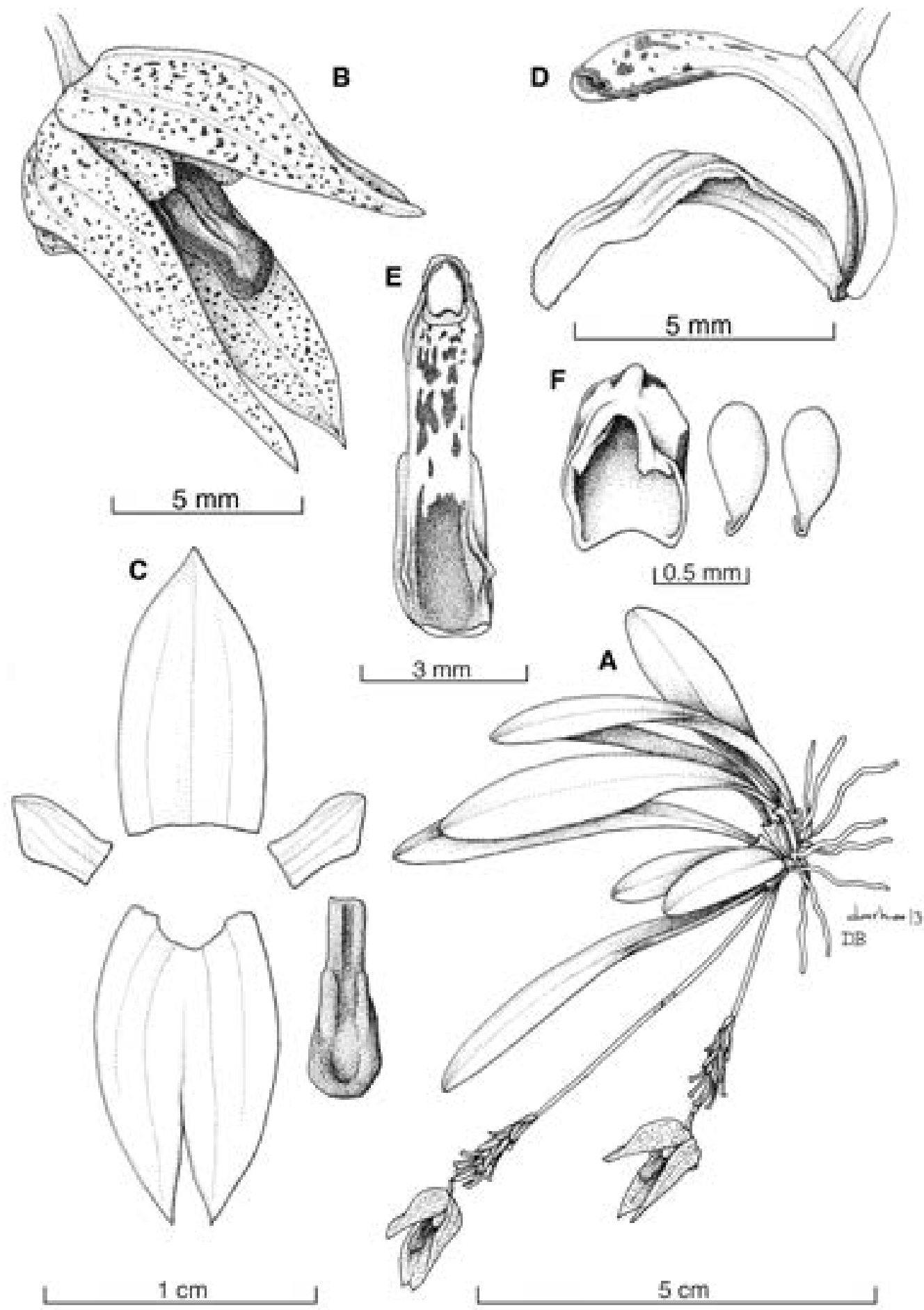

Figure 6. Specklinia condylata (Luer) Pridgeon \& M.W.Chase. A - Habit. B - Flower. C - Perianth, flatten. D - Column and lip, side view. E - Column. F. Pollinarium and anther cap. Drawn by D. Bogarín and D. Solano based on D. Bogarín et al. $10364(\mathrm{UCH})$. 

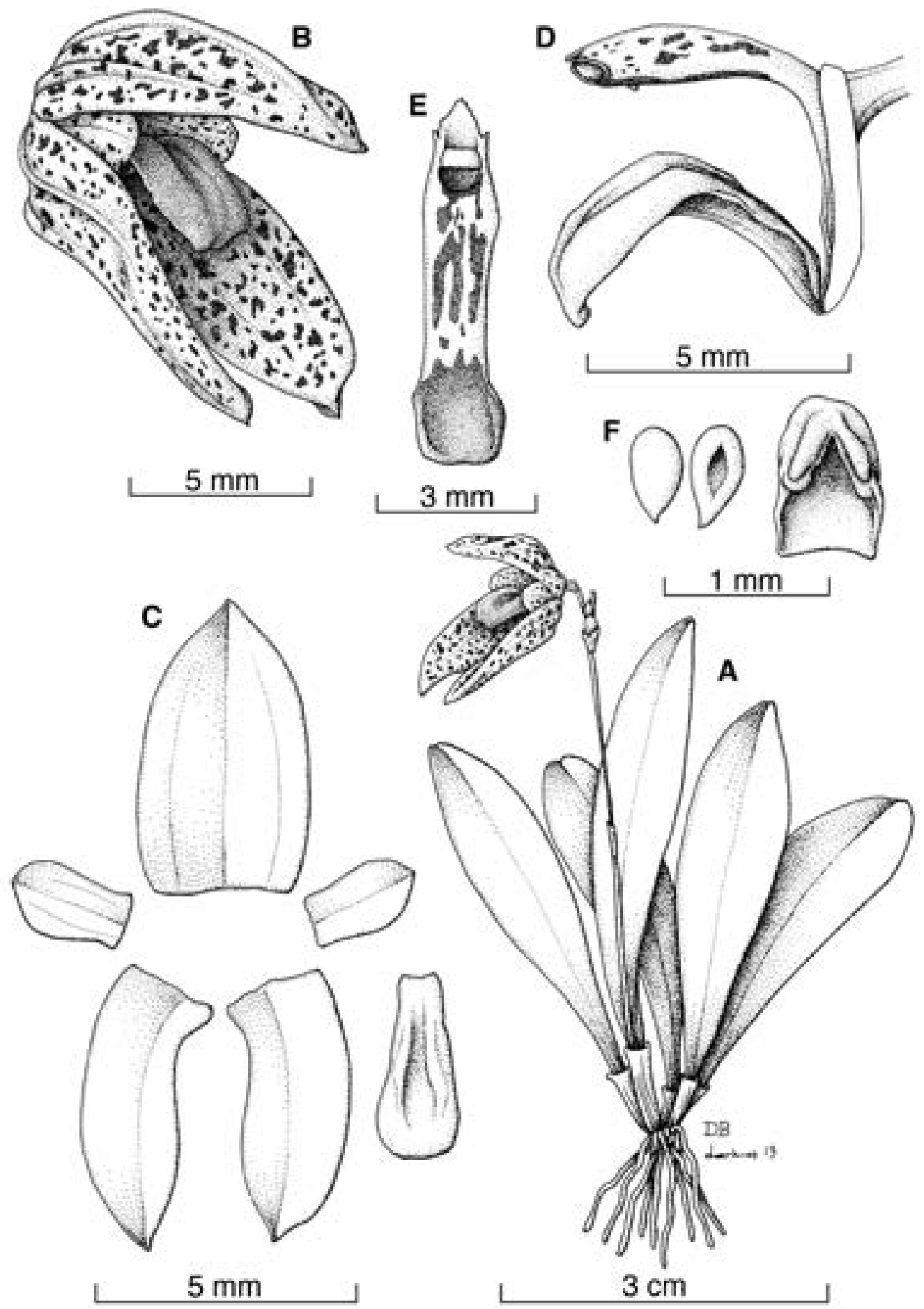

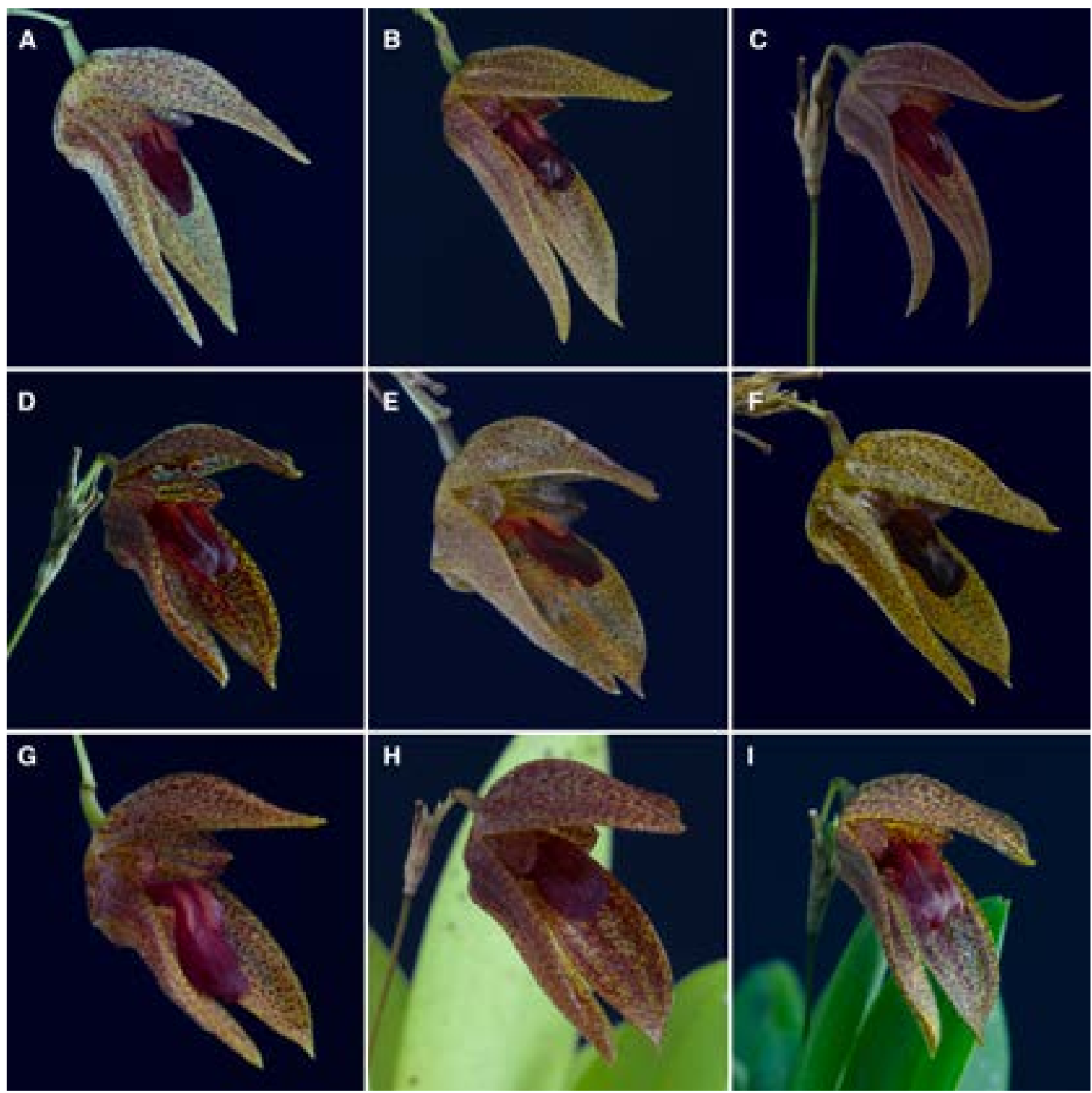

Figure 8. Comparison of the flower morphology of individuals of Specklinia condylata: A. (D. Bogarín 7855, Costa Rica). B. (M. Fernández 173, Costa Rica). C. (M. Fernández 171, Costa Rica). D. (D. Bogarín 7859, Costa Rica). E. (Z. Samudio s.n., Panamá). F. (D. Bogarín 10364, Panamá). G. (D. Bogarín 7855, Costa Rica). H. (D. Bogarín 7859, Costa Rica). I. (M. Fernández 168, Costa Rica).

$6.0 \mathrm{~cm}$ long, rachis up to $1 \mathrm{~cm}$ long. Floral bracts tubular, apiculate, conduplicate, membranaceous, imbricating, up to 2-4 mm long. Pedicel 4-7 $\mathrm{mm}$ long, persistent. Ovary to $3 \mathrm{~mm}$ long, glabrous, green or with purple spots. Flowers showy, hyaline, yellowish, sepals and petals densely speckled with purple-brown, the lip purple red, the column greenish stained with maroon. Dorsal sepal oblong-elliptic, acute, entire, reflexed, concave, 3-veined, dorsally keeled, connate to the lateral sepals for about $2 \mathrm{~mm}, 12.0-16.0 \times 3.3-6.0$ $\mathrm{mm}$. Lateral sepals oblong-ovate, acute, connate for 5-9 mm, forming a mentum at base, 3-veined, dorsally keeled, $12-17 \times 4-8 \mathrm{~mm}$. Petals oblique, obovatelanceolate, cuneate, acute, 3-veined, 4.5-5.0 × 2.0$3.0 \mathrm{~mm}$. Lip spatulate, obovate, basally unguiculate, with a pair of small lobules at the middle, adnate to the column foot, minutely erose to fimbriate, arcuate, obtuse, with two longitudinal, parallel, apically 


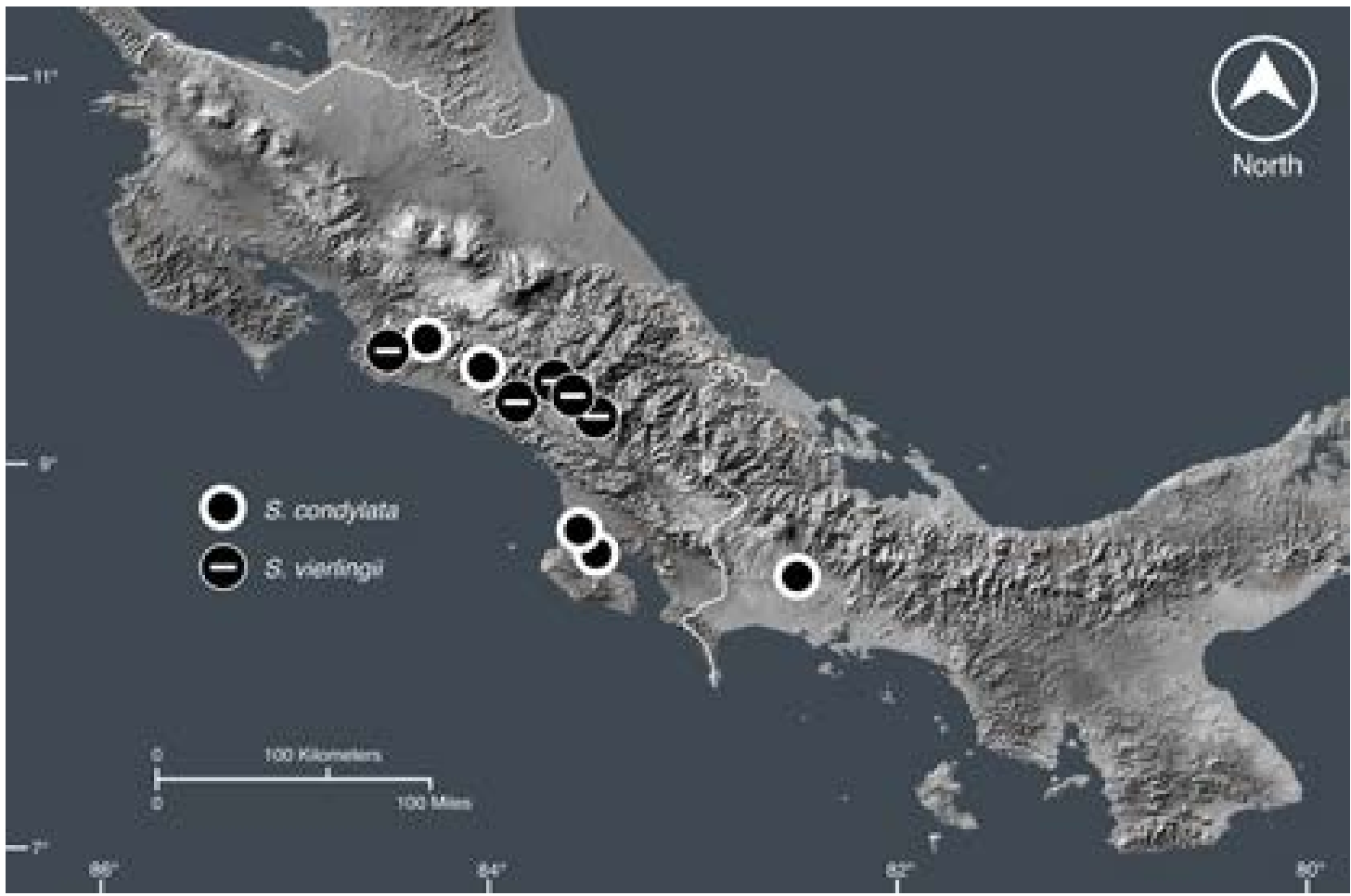

FIGURE 9. Geographic distribution of Specklinia condylata and Specklinia vierlingii.

convergent keels running up to the apex, forming two prominent cushions (whitish-yellowish) at the middle, sulcate, basally glutinose from the base towards the apex between the calli, 7.5-8.0 $\times 3.0-3.5 \mathrm{~cm}$, the apex often curved downward so appearing retuse. Column cylindrical, footed, to $9 \mathrm{~mm}$ long, with a pair of apical arms, erose, the anther and stigma ventral, greenish stained with purple. Pollinia two, ovoid, without viscidium, ending in a hook. Anther cap cucullate, white, stained with purple.

Distribution: endemic to the Pacific lowlands of Costa Rica and Panama.

HABITAT AND ECOLOGY: epiphytic in tropical wet forest on trees along streams and rivers, gallery forests and edge of mature vegetation in humid areas of the Pacific coast from central Costa Rica towards western Panama, from 200 to $600 \mathrm{~m}$ of elevation Luer (2006) cited two records of $S$. condylata from cultivated plants obtained from L. Acosta allegedly from 1500 and $1800 \mathrm{~m}$ (one in a quite odd location above San Cristóbal where no plants of this group have been seen in the field or in any herbaria). The other comes from above San Vito the type locality of $S$. icterina however it was not possible to check both specimens at MO. Although those records seem to considerably extend the elevation range of $S$. condylata, no other records of this species are known from 600 to $1800 \mathrm{~m}$. It seems that the locality given in the specimens of L. Acosta are erroneous or may correspond to a different species. Plants were observed growing on Zygia longifolia (Fabaceae) in Panama.

Eтymology: from the Latin condylatus, "with knuckles, or knuckled" and Greek kondylos "knuckle, fist", in allusion to the appearance of the lip of the type specimen.

Phenology: plants flower through the year but mostly from April to November.

Luer (1976) described this species from a collection in western Panama. He stated that the species is vegetatively similar to P. brighamii and its allies, although the flower is considerably larger and heavier. Luer (1976) characterized the species by the golden sepals and petals which are diffusely dotted with brownish-purple. The lip is deep purple, broadly dilated towards the deflexed apex, appearing truncate 


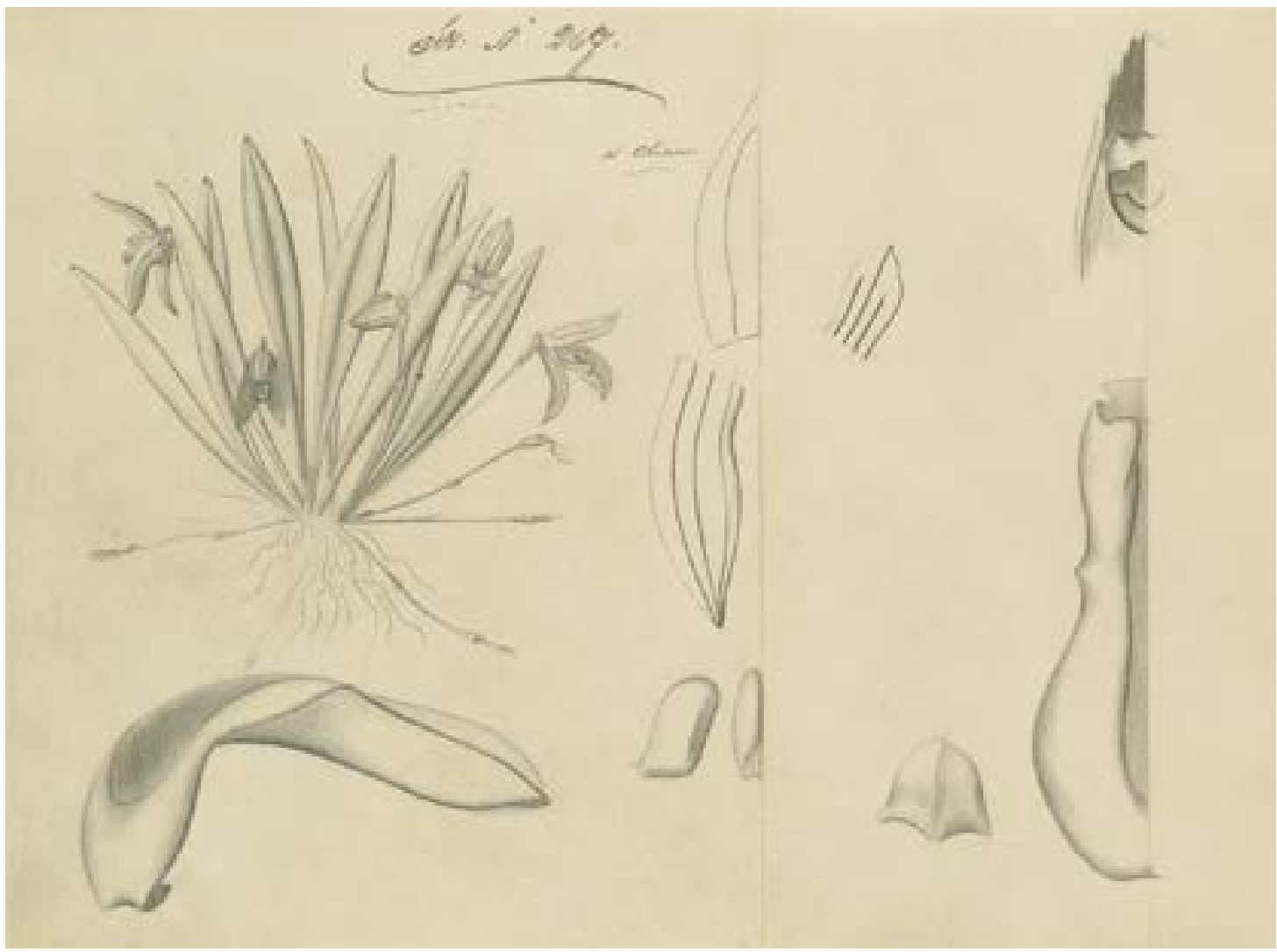

FiguRE 10. Drawing of Specklinia condylata by A.R. Endrés (W-0020241). Reproduced with the kind permission of the Herbarium, Naturhistorisches Museum, Wien.

or retuse, giving the appearance of two-knuckled fist in a gauntlet (Luer 2003). Luer (2006) also suggested a close relationship with $S$. areldii (Luer) Pridgeon \& M.W.Chase (see introduction).

Augustus R. Endrés collected and illustrated the first specimen attributed to this species in Costa Rica, however it was never published (W-0020241) (Fig. 10). Specklinia condylata is easily distinguished by the yellowish sepals densely speckled with purplebrown, and the pandurate lip, deep purple or reddish with yellowish calli at the middle. It is most similar to S. vierlingii however the latter species has yellowishcream flowers with purple speckles and blotches, sometimes with the veins purple (vs. yellowish, densely speckled with purple-brown) and the petals are narrowly oblong, $<1.5 \mathrm{~mm}$ wide (vs. obovatelanceolate, $>2 \mathrm{~mm}$ wide). Specklinia acoana is also similar but the latter species has white flowers with purple stains and the lip is shorter, $<5 \mathrm{~mm}$ long (rather than $>7.5 \mathrm{~mm}$ long). Lip size is similar between $\mathrm{S}$. condylata and S. vierlingii. Both species present a larger lip (> $7.5 \mathrm{~mm}$ long, $>3.0 \mathrm{~mm}$ wide) when compared to their allies (vs. $<5.0 \mathrm{~mm}$ long, $<2.5 \mathrm{~mm}$ wide). Other differences among its closest relatives are summarized in Table 1.

Plants gathered from the type locality in Panama show variation in the lip apex and coloration (Figs. $8 \mathrm{E}$, 8 F). The lip is often deflexed apically but not always and some flowers have a deep purple lip whereas others are reddish with yellowish calli (Fig. 4D, 4E). However, the characters cited by Luer (1976) in the protologue were also observed in the plants studied from the type locality. In Costa Rica, this species is also variable in the colour of flowers varying from yellowish to densely speckled with purple-brown and red to purple lip (Fig. 8). The lateral sepals are connate for $9 \mathrm{~mm}$ but sometimes they are almost free, connate to $5 \mathrm{~mm}$ (A.R. Endrés 267, W; M. Fernández 171, JBL). (Figs. 8H, 8E, 8c, 10). 
Additional material eXamined: Costa Rica. San José: Puriscal, Chires, Santa Rosa, Parque Nacional La Cangreja, orillas del Río Negro y Quebrada La

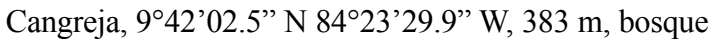
muy húmedo tropical, epífitas en árboles caídos, 27 julio 2010, D. Bogarín 7859, R.L. Dressler, M. Fernández \& C. Smith (JBL) (Figs. 7, 8H). Same locality, D. Bogarín 7855 (JBL-spirit) (Fig. 8A, 8G), M. Fernández 168 (Fig. 8I), M. Fernández 171 (Fig. 8C), M. Fernández 173 (JBL-spirit) (Fig. 8B) and M. Fernández 175 (JBL-spirit). Tarrazú: Boca de Dota [Santa Marta de San Lorenzo de Tarrazú], towards Cerro Pito, NovDec, A.R. Endrés 267 (W) (Fig. 10). Puntarenas: Osa, Sierpe, El Campo, subiendo por la fila entre Aguabuena y Baneguitas, cuenca superior de Quebrada Banegas, bajando hasta la Quebrada Digo digo, 842'00'N 83³1'00"W, 350 m, 13 enero 1991, G. Herrera 4818 (INB). Osa, Sierpe, San Juan, cuenca superior de Río

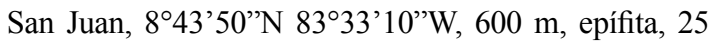
enero 1991, G. Herrera 4871 (INB). Panama. Chiriquí: Bugaba, La Estrella, orillas del río Escárrea, cerca de San Vicente, 8³2'01.96”'N 82³9'54.4”W, 253 m, epífitas en Zygia longifolia, 25 julio 2013, D. Bogarín 10364, Z. Samudio \& Z. Serracín (UCH) (Fig. 6, 8F). Same locality, Z. Samudio s.n., D. Bogarín \& Z. Serracín (UCH) (Fig. 8E). Chiriquí: sin más datos, obtenida de Finca Drácula, cultivada por Gerson Villalobos en Santo Domingo de Heredia, Costa Rica, 23 enero 2012, D. Bogarin 9452 (JBL-spirit).

\section{Specklinia icterina Bogarín, sp. nov.}

TYPE: Costa Rica. Puntarenas: Coto Brus, Limoncito, Jabillo, orillas del Río Cotón, ca. 500 m, invenit William Chacón, floreció en cultivo en el Orquidario Happy Garden, 20 abril 2011, D. Bogarin 8767 (holotype, JBL; isotype CR). Figs. 2G, 3, 4c, 11 .

Specklinia icterina is readily distinguished by the immaculate yellow, ovate, acute sepals and petals, the oblong lip with the apex obtuse but often curved downward so appearing retuse or emarginate, basally yellowish with purple from the middle towards the apex, the green immaculate ovary and column and the white anther cap.

Epiphytic, caespitose herb, up to $7.5 \mathrm{~cm}$ tall. Roots slender, flexuous, to $0.5 \mathrm{~mm}$ in diameter. Ramicauls slender, erect, $5-6 \mathrm{~mm}$ long, enclosed by 2 tubular sheaths up to $1 \mathrm{~cm}$ long. Leaves narrowly elliptic to obovate thick, coriaceous, acute, conduplicate, emarginate, with a short apiculus, $6.0-7.0 \times 1.0-0.8 \mathrm{~cm}$, cuneate, the base narrowing into a indistinct petiole less than $1 \mathrm{~cm}$ long. Inflorescence racemose, distichous, glabrous, patent, erect or suberect, successively singleflowered, born by a slender filiform peduncle, the rachis congested, appearing fasciculate, up to $7.5 \mathrm{~cm}$ long, usually longer than the leaves, peduncle up to $5.7 \mathrm{~cm}$ long, rachis up to $1.8 \mathrm{~cm}$ long. Floral bracts ovate, acute, conduplicate, membranaceous, tubular, imbricating, up to $5 \mathrm{~mm}$ long. Pedicels to $1 \mathrm{~cm}$ long, persistent. Ovary to $2 \mathrm{~mm}$ long, glabrous, green. Flowers the sepals and petals yellow, immaculate, the lip yellowish-cream basally, purple red apically, with the callus yellowish, the column green, the anther cap white. Dorsal sepal ovate, acute, entire, concave, 3 -veined, dorsally keeled, connate to the lateral sepals for about $1.5 \mathrm{~mm}, 13.5 \times 4.5 \mathrm{~mm}$. Lateral sepals ovate, acute, connate for $5 \mathrm{~mm}$, forming a mentum at base, 3-veined, dorsally keeled, $14.5 \times 8.5 \mathrm{~mm}$. Petals oblique, obovate, cuneate, acute, 3 -veined, $4.5 \times 2.0$ $\mathrm{mm}$. Lip oblong, basally unguiculate, adnate to the column foot, minutely denticulate, arcuate, obtuse, with two longitudinal, parallel, apically convergent keels running up to the apex, sulcate, basally glutinose from the base towards the apex between the calli, 5.0 $\times 2.5 \mathrm{~mm}$, the apex obtuse but often curved downward so appearing retuse or emarginate. Column cylindrical, footed, to $5.4 \mathrm{~mm}$ long, erose, arcuate, the anther and stigma ventral, greenish stained with purple. Pollinia two, ovoid, without viscidium, ending in a hook. Anther cap cucullate, white.

Distribution: only known from the southern Pacific in Costa Rica. It is likely found in Panama as one of the localities is about $3 \mathrm{~km}$ far away from the frontier. (Fig. 3).

HabitAT AND ECOLOGY: plants were found growing epiphytically in premontane wet forest, rain forest transition and tropical wet forest premontane belt transition in secondary and primary vegetation, from 500 to $920 \mathrm{~m}$ of elevation.

ETYMology: from the Latin icterinus or ictericus

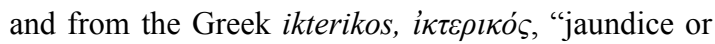
jaundiced" in allusion to the yellow coloured flowers. 


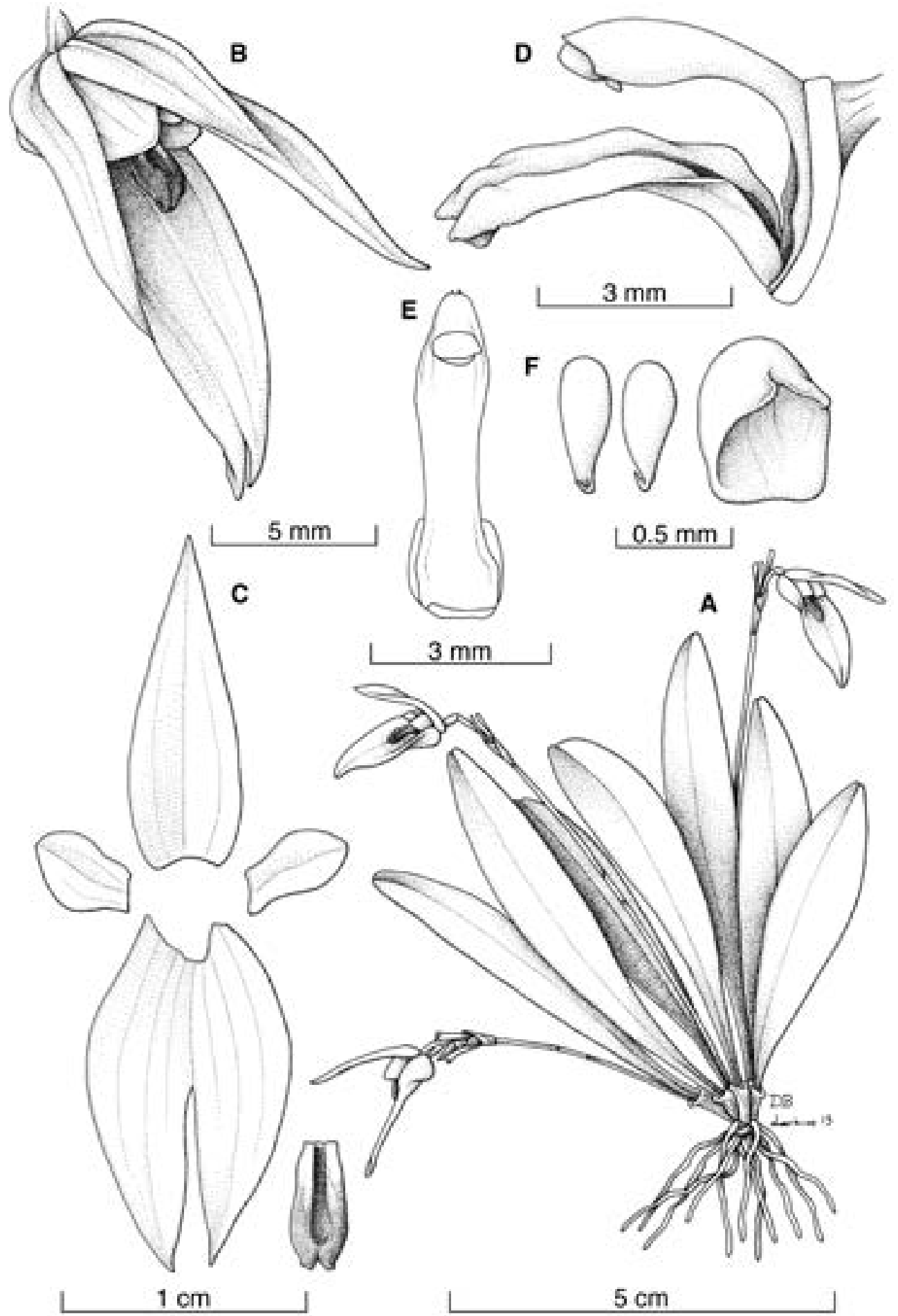

FiguRe 11. Specklinia icterina Bogarín. A - Habit. B - Flower. C - Perianth, flattened. D - Column and lip, side view. E - Column. F. -Pollinarium and anther cap. Drawn from the holotype by D. Bogarín and D. Solano. 
Phenology: plants flower through the year but mostly from May to October.

Specklinia icterina is restricted to the premontane forest of San Vito, Sabalito and neighbouring areas in southern Pacific of Costa Rica close to the boundary with Panama. The plant is vegetatively similar to its allies however the species is readily distinguished by the immaculate yellow, ovate, acute sepals and petals; the oblong lip basally yellowish and purple from the middle towards the apex; the green immaculate ovary and column; and the white anther cap (Figs. 2G, 11). Frequently the lip apex is curved or folded apically so appearing retuse (Fig. 4c). It also happens in S. acoana and $S$. condylata, its close relatives. However, those species have purple or red brown maculate, speckled sepals, petals and column. From S. condylata, it also differs in the oblong, shorter lip up to $5 \mathrm{~mm}$ long, tinged basally with yellow (vs. pandurate, 7.5-8.0 $\mathrm{mm}$ long, purple). Other differences among its closest relatives are summarized in Table 1.

Additional material examined: Costa Rica. Puntarenas: Coto Brus, Sabalito, Miraflores, $8^{\circ} 49^{\prime} 20^{\prime \prime}$ N 8254'42” W, 923 m, F. Oviedo-Brenes 2537 (HLDG). Coto Brus, San Vito, sin más datos, cultivada por Gerson Villalobos en Santo Domingo de Heredia, Costa Rica, 23 enero 2012, D. Bogarín 9453 (JBLspirit).

Specklinia vierlingii Baumbach, Orchideen (Hamburg) 63(5): 405-406. 2012.

TYPE: Costa Rica. s.l.; ex cult. hort. Gerhard Vierling;

leg. Norbert Baumbach et Jurgen Roth, 7 August

2012 (holotype, HAL). Figs. 2H, 2I, 9, 12.

Epiphytic, caespitose, pendent or suberect, herb, up to $6.5 \mathrm{~cm}$ tall. Roots slender, flexuous, to $0.5 \mathrm{~mm}$ in diameter. Ramicauls slender, erect, terete, to $5 \mathrm{~mm}$ long, enclosed by 2 tubular sheaths up to $1 \mathrm{~cm}$ long. Leaves narrowly obovate, thick, coriaceous, acute, conduplicate, emarginate, with a short apiculus, 2.5$6.5 \times 0.6-1.0 \mathrm{~cm}$, cuneate, the base narrowing into a indistinct petiole less than $4 \mathrm{~mm}$ long. Inflorescence racemose, distichous, glabrous, pendent or suberect, successively single-flowered, born by a slender filiform peduncle; peduncle bracts tubular to $3 \mathrm{~mm}$ long, the rachis congested appearing fasciculate, up to $6 \mathrm{~cm}$ long, peduncle $4.2-5.2 \mathrm{~cm}$ long, rachis up to $1.1 \mathrm{~cm}$ long. Floral bracts tubular, apiculate, conduplicate, membranaceous, imbricating, up to 4 $\mathrm{mm}$ long. Pedicels $6 \mathrm{~mm}$ long, persistent. Ovary to 3 $\mathrm{mm}$ long, glabrous, green spotted with red. Flowers showy, yellowish, the sepals stained or speckled with purple red from the centre towards the apex, the dorsal sepal adaxially striped with purple, the petals yellow with red purple stripes and purple apex, the lip purple red, the column greenish-yellow with purple red stripes. Dorsal sepal oblong, acute, entire, reflexed, slightly arcuate, 3 -veined, dorsally keeled, connate to the lateral sepals for about $2 \mathrm{~mm}, 12.0-14.0 \times 5.0-5.5$ $\mathrm{mm}$. Lateral sepals oblong-ovate, acute, connate for $6.5 \mathrm{~mm}$ into a ovate, acute, basally concave, entire, bifid synsepal, forming a mentum at base, 3-veined, dorsally keeled, $12-14 \times 6-7 \mathrm{~mm}$. Petals narrowly oblong, acute, 4.0-5.0 × 1.0-1.5 mm, subfalcate, 2-veined, with reflexed apex. Lip spatulate, obovate, basally unguiculate, with a pair of small lobules at the middle, adnate to the column foot, erose or fimbriate, arcuate, obtuse, with two longitudinal, parallel, apically convergent keels running up to the apex, sulcate, basally papillose and glutinose from the base towards the apex between the calli, with the apex rarely folded, 8.0-10.0 × 3.5-4.0 mm. Column cylindrical, footed, to $1.2 \mathrm{~cm}$ long, with a pair of apical arms, erose, the anther and stigma ventral, with purple dots and stripes along the margin. Pollinia two, ovoid, without a viscidium, ending in a hook. Anther cap cucullate, white, stained with purple.

Distribution: only known from central and southern Pacific lowlands in Costa Rica. (Fig. 9)

HABITAT AND ECOLOGY: epiphytic in tropical wet forest, tropical moist forest premontane belt transition and tropical moist forest in secondary and primary forest along humid patches of forest and river banks in the Pacific watershed of Cordillera de Talamanca from the central Pacific through Valle de El General and Fila Costeña in Costa Rica between 300 to $650 \mathrm{~m}$ of elevation.

EPONYMY: named after Gerhard Vierling, who cultivates this species in Germany.

Phenology: plants flower through the year but mostly from May to November. 


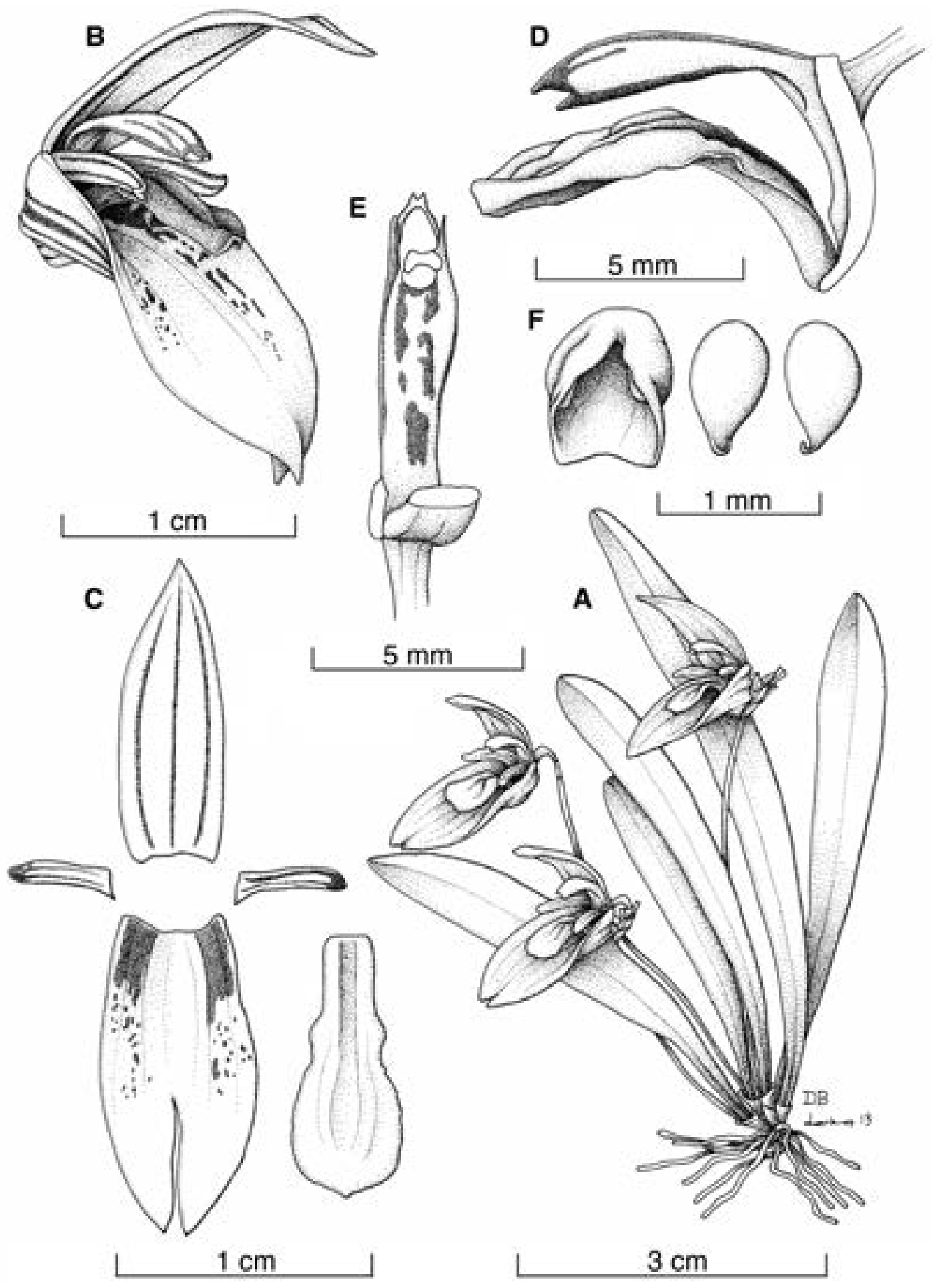

FIGURE 12. Specklinia vierlingii Baumbach. A - Habit. B - Flower. C - Perianth, flattened. D - Column and lip, side view. E-Column. F - Pollinarium and anther cap. Drawn by D. Bogarín and D. Solano based on F. Pupulin 2894 (JBL-spirit). 
This species was published by Baumbach (2012) based on a plant collected in Costa Rica and imported to Germany. According to the protologue, the plant comes from the Botanischer Garten Heidelberg and has been in culture by Gerhard Vierling. The holotype was deposited outside of the country of origin (HAL). During the preparation of this research, this species was well known by the authors for several localities in central and southern Pacific in Costa Rica, where it is endemic. It is clearly characterized by the yellowishcream flowers with purple speckles or blotches, sometimes with purple veins. The most important feature to recognize this species is the narrowly oblong petals to $4.0-5.0 \times 1.0-1.5 \mathrm{~mm}$, unique among its relatives. Baumbach (2012) differentiated $S$. vierlingii from $S$. condylata by the much bigger flower size and the fimbriate lip. However, we found that floral measurements overlap between $S$. condylata and $S$. vierlingii (Table 1) and the lip is also fimbriate in both species (see the discussion of $S$. condylata and Table 1) (Fig. 4D-4F).

The illustration provided in the protologue by Baumbach (2012) is confusing and it mixes features of $S$. condylata. At least, he copied exactly the plant habit from the original drawing of $P$. condylata by Luer (1976). The drawing shows the same four leaves, roots and inflorescence that C. Luer drew for $P$. condylata. The flower dissection and the lateral view of the column and lip were also copied with a little modification of the lip apex and petals and they do not represent its real morphology. The drawing by Baumbach (2012) does not agree with the morphology of $S$. vierlingii as it was exactly copied from the drawing of the type of $S$. condylata (Luer 1976).

This species was intended to be published in this paper therefore, we provide the data we had prepared for its description such as full locality data, distribution map, illustrations and pictures of several individuals, a composite plate based on a living plant and a comparison among its closest relatives (Table 1) to aid with a proper identification of this species.

Additional material examined: Costa Rica. San José: Pérez Zeledón, El Brujo, road to El Llano, along the boarder of Río División, $320 \mathrm{~m}, 9^{\circ} 25^{\prime} 40^{\prime \prime} \mathrm{N}$ $83^{\circ} 54^{\prime} 58^{\prime \prime} \mathrm{W}$, epiphytic on tall trees along the river shore, 21 January 2001, F. Pupulin 2823, D.
Castelfranco \& L. Elizondo (JBL-spirit). Same locality, F. Pupulin et al 2894 (JBL-spirit) (Fig. 2H, 12). Pérez Zeledón, Viento Fresco de El Brujo, along the Quebrada del Camarón, about $450 \mathrm{~m}, 9^{\circ} 25^{\prime} 13^{\prime \prime} \mathrm{N}$ $83^{\circ} 56^{\prime} 27^{\prime} \mathrm{W}$, epiphytic in disturbed primary forest, wet premontane forest, 20 January 2001, F. Pupulin 2817, D. Castelfranco \& L. Elizondo (JBL-spirit). Same locality, F. Pupulin et al 2816 (JBL-spirit). San Isidro de General, barrio El Hoyón, márgenes del Río Pedregoso, $650 \mathrm{~m}$, epífita en troncos musgosos de Ficus sp., floreció en setiembre del 2002 en cultivo de la familia Valverde Arias, Desamparados, San José, R. Valverde 160 (JBL-spirit). Pérez Zeledón, General, Peñas Blancas, orillas del Río Caliente, 9¹9’33.0” N 83³7'10.6” W, 629 m, bosque húmedo tropical, transición a premontano, en bosque secundario remanente a orillas del río, 28 julio 2009, D. Bogarín 7350, J. Cambronero \& F. Pupulin (JBL-spirit) (Fig. 2I). Pérez Zeledón, R.F. Los Santos, Savegre Abajo, Finca de Neftalí Cordero, Fila el Zoncho, 9²7'18.0" N 8351'09.7”'W, 900 m, 11 mayo 1999, A. Estrada 2185 (CR). Turrubares, Parque Nacional Carara, Valle del Tárcoles, Estación Bijagual, 945’30” N 84³3'10” W, 600 m, 26 julio 1995, M. M. Chavarría 895 (INB-spirit).

\section{KEY TO THE SPECIES OF SPECKLINIA CONDYLATA GROUP}

1. Sepals and petals yellow, immaculate; base of the lip yellowish S. icterina

1. Sepals and petals maculate, stained or speckled; base of the lip purple 2

2. Lip $>7.5 \mathrm{~mm}$ long, $>3.0 \mathrm{~mm}$ wide, column $>9 \mathrm{~mm}$ in length

2. Lip $<5.0 \mathrm{~mm}$ long, $<2.5 \mathrm{~mm}$ wide, column $<6.5 \mathrm{~mm}$ in length 4

3. Petals narrowly oblong, $<1.5 \mathrm{~mm}$ wide S. vierlingii

3. Petals obovate-lanceolate, $>2 \mathrm{~mm}$ wide S. condylata

4. Flowers whitish with stains and blotches dispersed on the sepals, sepals connate to $5 \mathrm{~mm}, 12.0 \times 7.0 \mathrm{~mm}$

S. acoana

4. Flowers yellowish with stains and blotches along the veins of the sepals, sepals connate to $1.5 \mathrm{~mm}, 9.4 \times 6.3$ $\mathrm{mm}$

S. berolinensis 
ACKNOWLEDGMENTS. The scientific services of Ministerio del Ambiente, Energía (MINAE) and Sistema Nacional de Áreas de Conservación (SINAC) of Costa Rica and Autoridad Nacional del Ambiente (ANAM) of Panama for issuing the scientific permits, under which wild specimens were managed. We are indebted to Clotilde Arrocha, Ivonne Oviedo, Franco Pupulin, Rafael Rincón and Jorge Warner for their continuous support on the study of orchids in Panama. Darha Solano for finely inking the illustrations. Daniel Jiménez, Daniel Matamoros, Federico Oviedo-Brenes (HLDG), Jeremy Quesada and Gerson Rodríguez kindly provided data and plant material. Two anonymous reviewers greatly improved the manuscript. This research was enabled by the Project 814-B2-161 "Hacia una moderna flora de orquídeas de Panamá" by JBL and Herbario UCH, supported by the Vice-Presidency of Research, Universidad de Costa Rica and Universidad Autónoma de Chiriquí and "Flora Costaricensis: Taxonomía y Filogenia de la subtribu Pleurothallidinae (Orchidaceae) en Costa Rica" (814-BO-052).

\section{LitERATURE CITED}

Baumbach, N. 2012. Eine neue Specklinia-Art a us Costa Rica. Orchideen (Hamburg) 63(5): 404-406.

Bogarín, D., A.P. Karremans, R. Rincón \& B. Gravendeel. 2013. Anew Specklinia (Orchidaceae: Pleurothallidinae) from Costa Rica and Panama. Phytotaxa 115(2): 31-41.

Bolaños, R., V. Watson \& J. Tosi. 2005. Mapa ecológico de Costa Rica (Zonas de Vida), según el sistema de clasificación de zonas de vida del mundo de L.R. Holdridge. Scale 1:750 000. Centro Científico Tropical, San José, Costa Rica, 1 p.

Garay, L.A. 1974. Acostaea y los géneros del complejo Pleurothallis. Orquideología 9: 103-124.

Garay, L.A. \& H.R. Sweet. 1972. Notes on West Indian orchids. J. Arnold Arbor. 53: 515-530.

Holdridge, L. R. 1987. Ecología basada en zonas de vida, $3^{\text {a }}$ reimpresión. Instituto Interamericano de Cooperación para la Agricultura (IICA), San José, Costa Rica, 216 pp. Lindley, J. 1830. The genera and species of orchidaceous plants 8. Asher, London. xvii, $554 \mathrm{pp}$.

Lindley, J. 1859. Folia Orchidacea, an enumeration of the known species of Orchids, 43: Pleurothallis part 2. $1-46$.

Luer C.A. 1976. Miscellaneous species of Pleurothallis. Selbyana 3(1-2): 38-201.

Luer, C.A. 1986. Systematics of Pleurothallis (Orchidaceae). Icones Pleurothallidinarum III. Monogr. Syst. Bot. Missouri Bot. Gard. 20.

Luer, C. A. 2002. A systematic method of classification of the Pleurothallidinae versus a strictly phylogenetic method. Selbyana 23(1): 57-110.

Luer, C.A. 2003. Pleurothallis. Pp. 386-452 in: B.E. Hammel, M.H, Grayum, C. Herrera \& N. Zamora (eds.), Manual de Plantas de Costa Rica. Volumen III: Monocotiledóneas (Orchidaceae-Zingiberaceae). Monogr. Syst. Bot. Missouri Bot. Gard. 93.

Luer, C.A. 2006. A reconsideration of Masdevallia. Systematics of Specklinia and vegetatively similar taxa (Orchidaceae). Icones pleurothallidinarum XXVIII. Monogr. Syst. Bot. Missouri Bot. Gard. 105.

Pridgeon, A.M. 2005. 355. Specklinia. Pp. 402-405 in: A. M. Pridgeon, P.J. Cribb, M.W. Chase \& F.N. Rasmussen (eds.), Genera orchidacearum Vol. IV. Oxford University Press, Oxford, UK.

Pridgeon, A.M. \& M.W. Chase. 2001. A phylogenetic reclassification of Pleurothallidinae (Orchidaceae). Lindleyana 16: 235-271.

Pridgeon, A.M., R. Solano \& M.W. Chase. 2001. Phylogenetic relationships in Pleurothallidinae (Orchidaceae): combined evidence from nuclear and plastid DNA sequences. Amer. J. Bot. 88: 2286-2308.

Pupulin, F., A.P. Karremans \& B. Gravendeel. 2012. A reconsideration of the empusellous species of Specklinia (Orchidaceae: Pleurothallidinae) in Costa Rica. Phytotaxa 63: 1-20. 